\title{
Schijnbare syntactische feniksen
}

\author{
Freek Van de Velde
}

\author{
NT 20 (1): 69-107 \\ DOI: 10.1557/10.5117/NEDTAA2015.1.VELD
}

\begin{abstract}
Apparent syntactic phoenixes

This article investigates 'syntactic phoenixes': obsolete or obsolescent constructions that unexpectedly regain currency in language use. Four case studies are investigated to gain insight in the reasons for the revival of these old constructions: (i) transparent free relatives, (ii) the complex prepositionlike combination wat betreft, (iii) accusativus and nominativus cum infinitivo $(\mathrm{ACl} / \mathrm{NCl}$ ) and (iv) bare infinitive with the young modal hoeven. In all cases, the (temporary) reversal of the diachronic trends in the internal syntax of these constructions is argued to be driven by an analogical pull by cognate constructions. As such, the phoenixes are in fact illusions: the revival only affects a particular corner of the whole construction, namely where it borders on the neighbouring construction. The diachronic developments underscore the need to take into account the impact of the broad grammatical environment in which syntactic changes take place in grammaticalisation.
\end{abstract}

Keywords: grammaticalisation, analogy, construction grammar, obsolescence, revival, transparent free relatives, ACI, NCI, modal, phoenix

\section{$1 \quad$ Inleiding ${ }^{1}$}

Grammaticale constructies kunnen verouderen en uiteindelijk verdwijnen uit de taal. Historische grammatica's (Weijnen 1971; Van der Horst 2008)

1 Graag zou ik de vaste redactie en de gastredactie bedanken voor eerdere commentaren op dit artikel, en verder ook Hendrik De Smet, wiens expertise ik van harte kan aanbevelen aan iedereen die corpora gebruikt en op een probleem stuit. 
liggen bezaaid met dergelijke antiquiteiten, zoals de onpersoonlijke datiefgenitief-constructie (1), post-demonstratieve possessiva (2), niet-IPP gebruik van perfectief doen (3) of asyndetische relatiefzinnen (4), om maar een willekeurige greep te doen uit een ruim aanbod. Geen van deze constructies komen nog voor in het hedendaagse Standaardnederlands.

(1) den apostelen wonderde des (ca. 1300-1325, Spiegel historiael) 'de apostelen waren daar verwonderd over'

(2) dese mijn zone (1399, N.T. in de Nndl. vert. - Lucas [XII-XXIV]) 'deze zoon van mij'

(3) Hy hadde binnen zijn levene grootelicx ghedaen vermeerderen die abdie van St-Pieters te Ghendt (16de eeuw, Van der Horst 2008: 901) 'Hij had tijdens zijn leven in hoge mate de abdij van Sint-Pieters in Gent doen vergroten'

(4) Een dorper, heet Lamfroit, woont hier bi (ca. 1275-1300, Van den vos Reynaerde, Weijnen 1971: 64)

'Een dorpeling, die L. heet, woont erbij'

In de meeste gevallen lijkt op dit soort grammaticale fossielen de biologische Wet van Dollo van toepassing, die zegt 'weg is weg': een organisme kan niet terugkeren naar een voorouderlijk stadium, althans niet in dezelfde vorm. De datief is voorgoed weg uit het Nederlands. ${ }^{2}$ Misschien krijgen we ooit nog wel een nieuwe datiefnaamval, maar dan wellicht toch niet in dezelfde vorm als wat het Middelnederlands te zien geeft. Idem voor negatie: in taal na taal zien we het optreden van cyclische processen van negatievernieuwing die bekend staan als de 'Jespersen Cycle' (een term van Dahl 1979. Zie, voor het Nederlands, Van der Auwera 2012 en de literatuur waarnaar hij verwijst), maar de oude negatie heeft een andere origine en uitzicht dan de nieuwe. ${ }^{3}$ Zulke cyclische bewegingen (Van Gelderen 2011) zijn niet in tegenspraak met de Wet van Dollo.

$\mathrm{Nu}$ is taalverandering - of meer in het algemeen: culturele evolutie minder star dan biologische evolutie, en soms komt het toch voor dat oude patronen weer ingang vinden in de taal. Een in de vakliteratuur al eerder beschreven voorbeeld is de 'ondode genitief' van Hoeksema (1998). In dit

2 Bedoeld is: de productieve morfologische datief, met uitsluiting van: versteende datieven ( $t e$ elfder ure), systeemvreemde pronominale datieven (hun) en indirecte objecten die teruggaan op datieven (hij heeft haar op de vingers getikt).

3 Soms líjkt een nieuw element wel heel erg op een oude dat het vervangt (zie Heath 1998). 
artikel zal ik een aantal andere curieuze gevallen bespreken waarin een dood gewaande constructie schijnbaar als een feniks verrijst.

Het is niet altijd gemakkelijk te zien of een constructie wel echt morsdood is (zie ook Hoeksema 1998: 162). ${ }^{4}$ Neem de heropleving van de subjunctive in mandative complements in het Amerikaans Engels zoals bijvoorbeeld in She insisted he do that (zie Leech e.a. 2009: 60-70). Om nu te zeggen dat die subjunctive helemaal weg was in het Engels, gaat de meeste taalkundigen te ver, maar dat maakt de merkwaardige toename in het gebruik ervan niet minder spectaculair.

De feniks hoeft dus niet helemaal tot as vergaan te zijn, maar kan ook een rottend kreng zijn, ${ }^{5}$ of misschien zelfs een zieltogend, vleuggellam vogeltje.

Dat taalgebruikers, die op een handvol taalkundigen na niet bijzonder goed ingelicht geacht mogen worden over de geschiedenis van de syntaxis, ertoe komen om voorouderlijke constructies nieuw leven in te blazen, mag verbazing wekken, en in dit artikel wordt dan ook aandacht besteed aan de mechanismen die achter dit merkwaardige proces schuilgaan. Uit de bespreking zal blijken dat het achterliggende proces analogie is. Stel dat van een bepaalde constructie een 'verouderde' variant A en een 'innovatieve' variant B bestaat. Als variant A tegen de gang van zaken in toch opflakkert, dan is dat in de gevallen die in $\S 3$ de revue passeren het gevolg van analogische aantrekking door een andere constructie C. Het is dan ook niet de hele constructie (of constructionele variant) die plots weer opveert, maar alleen een hoekje van het gebruik ervan, precies daar waar een naburige constructie opspeelt.

Een voorbehoud bij het onderzoek naar syntactische feniksen in dit artikel en bij de verklaring die hier voorgesteld wordt, is dat rekening moet worden gehouden met het fenomeen dat bepaalde patronen gefloreerd hebben in de dialecten, onder de radar van onze geschreven corpusdata. De heropleving is in dat geval niet per se te danken aan analogische attractoren, maar aan het feit dat een taalvariëteit opnieuw dagzoomt in een bepaalde periode in de corpora. Ik heb echter geen aanwijzingen kunnen vinden voor deze alternatieve verklaring: de tendensen in de geval-

4 De discussie wordt ook gevoerd in de internationale literatuur in de context van 'exaptatie', het opportunistisch recycleren van morfologie. Lass (1990) heeft het in dat verband aanvankelijk over functieloze, dode 'junk morphology', maar verschillende auteurs hebben nadien kanttekeningen geplaatst bij notie 'junk' (Vincent 1995: 435, Giacalone Ramat 1998, Smith 2006 en Willis 2010), en ook Lass neemt in later werk gas terug (Lass 1997: 318).

5 Dat schijnt in de mythologie trouwens een variant te zijn van het feniksverhaal. 
studies lijken zich heel breed voor te doen. ${ }^{6}$ Maar ik heb er ook niet systematisch naar gezocht, dus als vervolgonderzoek dieper kijkt naar regionale patronen en daar een trend in kan ontwaren, dan kan dat een mogelijk ander licht werpen op wat in het vervolg van dit artikel te lezen valt.

Het bestaan van deze syntactische feniksen is om twee redenen relevant voor het onderzoek naar grammaticalisatie. Allereerst laten de syntactische feniksen zien dat grammaticalisatieprocessen geen zelfaangedreven evoluties zijn langs universele paden, maar duidelijk ingeperkt worden door de particuliere structurele omgeving: er zijn weliswaar terugkerende grammaticalisatiepaden (beweging $>$ toekomst, lichaamsdeel $>$ voorzetsel etc., zie Heine \& Kuteva 2002), maar welke koers een bepaald proces volgt, hangt sterk samen met de contingente relaties in de grammatica van een bepaalde taal. Dat aspect, de rol van de syntactische omgeving, verdient wat meer uitleg, die wordt gegeven in de volgende sectie (§2). Ten tweede tonen de syntactische feniksen de doorslaggevende rol van analogie als een mechanisme in grammaticalisatie. Die rol komt in recent onderzoek steeds meer centraal te staan (zie o.a. Fischer 2007, 2008, 2011; De Smet 2009; Bybee 2010, met name ook voor de cognitieve principes achter het mechanisme van analogie in de taal), maar is ook vroeger al erkend in het werk van Paul (1898) en te onzent in het werk van Van Marle \& Koefoed (1980), Van Bree (1996) en Hüning (1999: 24-33). ${ }^{7}$

\section{De rol van de structurele omgeving in taalverandering}

Het is binnen de zogeheten gebruiksgebaseerde benadering gemeengoed dat taalverandering in het algemeen, en 'grammaticalisatie' in het bijzonder, niet plaatsvindt in geïsoleerde woorden, maar in een specifieke context (Bybee e.a. 1994: 11; Croft 2000: 62, 156, 163; Heine 2003: 575; Bybee 2003: 602-603, 2007; Traugott 2003; Himmelmann 2004; Gisborne \& Patten 2011). In de lijn van die vaststelling, maar minder vaak opgemerkt, ligt het idee dat taalverandering niet alleen plaatsvindt in een specifieke context, maar ook vergemakkelijkt kan worden of gehinderd kan worden door de bredere 'structurele omgeving', de syntagmatische en paradigmatische contouren van de grammatica (zie Mithun 1991: 16o; Plank 2004; Rosenbach 2010;

6 'Breed' betekent daarom nog niet per se: in het hele taalgebied. De ontwikkeling van hoeven (\$3.4) speelt zich hoofdzakelijk af buiten het zuiden om, omdat hoeven daar sowieso niet zo sterk ingeburgerd is.

7 Zie ook Hoeksema (1998: 162) over de rol van analogie in het voortleven of opleven van oude patronen. 
Davidse e.a. 2010: 2-3; De Smet 2010, 2012). Die kan gunstig zijn, zodat veranderingen in goede grond vallen. Om een eenvoudig voorbeeld te geven: een taal met postposities zal die gemakkelijk kunnen laten grammaticaliseren tot suffixen, omdat die postposities al achter het nomen staan. Een ander voorbeeld is de grammaticalisatie van de V2-positie, die vergemakkelijkt werd omdat veel lichte hulpwerkwoorden, met name in het 'geanalytiseerde' Germaans, toch al sowieso op de tweede zinspositie kwamen door de Wet van Wackernagel (zie Hopper 1975): eerst zijn de lichte werkwoordjes in V2 geplaatst, een positie die sowieso erg gegeerd is bij partikels en andere kleine elementjes. Nadien zijn, analogisch, zwaardere werkwoorden in V2 gekomen, waardoor V2 gesemiotiseerd werd als taalteken (in de zin van Van der Horst 1995).

Maar er is meer: de structurele omgeving blijkt door taalgebruikers ook uitgebuit te kunnen worden om er zo voor te zorgen dat taalveranderingen een niet al te ontwrichtend effect hebben. Een voorbeeld, uit het Engels, is de zogenoemde 'modal raising' in de can't-seem-to constructie (zie o.a. Plank 1984: 315). De Engels modale hulpwerkwoorden hebben de mogelijkheid verloren als infinitief op te treden, vgl. (5) vs. (6), en het ontbreken van deze vorm maakt het onmogelijk het hulpwerkwoord te gebruiken als complement van seem in het hedendaags Engels, zie (7), waartegen op semantische gronden eigenlijk geen bezwaar bestaat. Wat doet de taalgebruiker in dit geval? Die past 'modal raising' toe, waarbij can meelift met de ontkenning, door tersluiks het frequente brokje can't te gebruiken, en op die manier het ontwrichtende effect van de verandering in de syntaxis van can te temperen, zie (8). De structurele omgeving is hier dus het paradigmatische verband met andere gevallen van negatie-clisis can't.

(5) Cryseyde shal not conne knowe me (14de eeuw, OED s.v. can, v. ${ }^{1}$ )

'C. zal me niet kunnen (her)kennen'

(6) *Criseyde shall not can know me

(7) *I don't seem to can find my wallet

(8) I can't seem to find my wallet

Een ander geval, uit het Nederlands, is de lijdende vorm van het causatieve laten + naakte infinitief. Zo'n combinatie is semantisch gezien geen probleem: je hebt er wordt getoond, dus waarom niet er wordt laten zien? Maar er wringt iets in deze constructie: door het infinitivus-pro-participio-effect (IPP) in het Nederlands kan het werkwoord laten hier niet als voltooid deelwoord verschijnen. Hoewel patronen van het type er wordt laten zien in het wild voorkomen (Coppen 2001, 2006), doen sommige taalgebruikers 
iets anders: ze vervangen de door laten geregeerde infinitief door het voltooid deelwoord: Waarom moeten dan juist de shockerendste beelden worden laten gezien (Coppen 2006). Laten regeert normaal gezien geen voltooid deelwoord, maar de combinatie Aux $x_{\text {Finiet }} \operatorname{Aux}_{\text {Infinitief }} \mathrm{V}_{\text {Volt.dlw. bestaat }}$ wel (bv. ze moeten dat hebben ingezien), en dat laatste patroon kan analogisch soelaas bieden om zowel IPP als voltooid-deelwoord markering te realiseren in het passieve causatieve laten.

Het 'opportunistisch uitbuiten' van de structurele omgeving door taalgebruikers, waarvan zo-even sprake was, moet niet begrepen worden als een tactische zet van sprekerswege, maar veeleer als een onbedoeld effect: de taalgebruiker is in staat analogische verbanden te leggen tussen verwante constructies (zie Bybee 2010 voor tal van voorbeelden), en doet dit - onbewust - ook wanneer hij op lokale, dubbelzinnige structuren stuit, waarmee de taalgebruiker in principe verschillende kanten uit kan (zie Van de Velde \& Van der Horst 2013 voor uiteenlopende voorbeelden uit de historische grammatica van het Nederlands). Als voldoende taalgebruikers convergeren in het gebruik van die opportunistische analogieën, dan kunnen daaruit nieuwe patronen ingesleten geraken in de taal (zie ook de 'onzichtbare hand' van Keller 1990). Wat eerst een lokale afwijking lijkt (bv. het wordt laten gezien), kan een productieve constructie worden: SYN AUX-

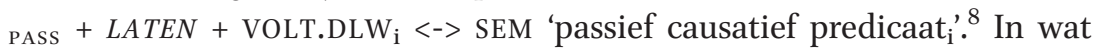
volgt, wordt ingegaan op vier gevalstudies waarin de taalgebruiker schijnbaar terug grijpt naar verouderde patronen in heranalyseprocessen.

\section{Gevalstudies}

\subsection{Transparante vrije relatiefzinnen}

Het Nederlands bezit, net als het Engels, een constructie die 'transparante vrije relatiefzin' genoemd wordt, een term die door Wilder (1999) geïntroduceerd is voor feiten die voordien al aan bod gekomen waren in McCawley (1988, hfst. 22, met verwijzing naar nog vroeger werk van Kajita). ${ }^{9}$ Het gaat om gevallen van het volgende type:

8 Ik gebruik hier een vrije constructiegrammaticale notatie, waarbij een vorm (SYN) aan een betekenis (SEM) gekoppeld wordt (met het teken <->), maar doe hier geen voorstel voor een heel precieze formalisatie.

9 Voor de notie 'constructie' volg ik hier de nogal genereuze opvatting van veel constructiegrammaticaal werk waarin zowel open, halfopen, als heel concrete patronen als constructie kunnen doorgaan, op voorwaarde dat ze ingesleten ('entrenched') zijn en een karakteristiek vorm-betekenis-koppel vormen. 
(9) Wat eerst leek op "gewone" studies bleken complete kunstwerken te zijn. $^{10}$

Op het eerste gezicht hebben we hier te maken met een gewone betrekkelijke bijzin met ingesloten antecedent (wat ... studies), ook wel 'vrije relatiefzin' genoemd (zie Haeseryn e.a. 1997: 329; Broekhuis \& Keizer 2012: 393) zoals in (10).

(10) Wat je hier ziet is gestolde lava na een gigantische uitbarsting van Mount Ngauruhoe. ${ }^{11}$

Het bijzondere van gevallen als (9) is dat zulke vrije relatiefzinnen syntactische trekken hebben die de gewone vrije relatiefzin in (10) vreemd zijn (zie ook Van Riemsdijk 2000a,b, Grosu 2003; Schelfhout e.a. 2004; Den Dikken 2005; Zwart 2006; Van de Velde 2007, 2009, 2010, 2011; Kluck 2011; Broekhuis \& Keizer 2012: 415-417). Zo zijn gewone vrije relatiefzinnen onveranderlijk enkelvoudig, terwijl de congruentie van het werkwoord van de rompzin (bleken) laat zien dat de vrije relatiefzin in (9) meervoudig opgevat moet worden. De oorzaak van dat verschil is dat de semantisch-syntactische kenmerken van een normale relatiefzin bepaald worden door het ingesloten antecedent in het relativum wat, dat een enkelvoudig getal heeft, en geparafraseerd kan worden als 'iets wat' of 'dat wat', terwijl in het geval van de transparante vrije relatiefzin (vanaf nu afgekort tot TVR) de rechtsperifere constituent - in (9) dus gewone studies - de morfosyntactische kenmerken van de hele relatiefzin bepaalt. In navolging van Schelfhout e.a. (2004) zal ik die rechtsperifere constituent de 'inhoudskern' noemen. ${ }^{12}$ Om de 'buitenbouw' van de transparante vrije relatiefzin te kunnen bepalen moeten we dus diep in de 'binnenbouw' kijken, dwars door het vrije relatiefpronomen heen, tot in de inhoudskern. Het vrije relatiefpronomen is met andere woorden 'transparant' - vandaar de naam van de constructie. De inhoudskern bepaalt niet alleen het getal van de TVR, maar ook andere semantisch-syntactische kenmerken, zoals definietheid, bezieldheid ('animacy'), NPI-vergunning ('negative polarity item licensing') enzovoort. Dat blijkt uit grammaticaliteitscontrasten tussen TVR'en en reguliere vrije relatiefzinnen (RVR'en). TVR'en kunnen indefiniet zijn, als

$10 \mathrm{http} / /$ startwarehouse.com/nl/bertslagt/, bezocht op 2013-03-29.

11 http://www.traveltheglobe.eu/Fotos/Nwznoord2/51.\%2owat\%2oje\%2ohier\%2oziet\%2ois\% 2ogestolde\%2olava\%2ona\%2oeen\%2ogigantische\%2ouitbarsting\%2ovan\%2oMount\%2oNgauruhoe.html, bezocht op 2013-03-29.

12 In het Nederlands staat de inhoudskern niet altijd rechtsperifeer. Ik kom daar later op terug. 
ze een indefiniete inhoudskern hebben, terwijl RVR'en onveranderlijk definiet zijn, en daarom niet kunnen voorkomen in presentatieve constructies, een klassieke test voor indefinietheid (zie Lyons 1999: 236-246), zie (11) vs. (12). Verwijzing naar bezielde entiteiten kan in RVR'en alleen met het pronomen wie, niet met het pronomen wat, terwijl TVR'en wat kunnen handhaven, en de verwijzing laten afhangen van de inhoudskern, zie (13) vs. (14), waarin het rompzinwerkwoord gesubcategoriseerd is voor een bezielde entiteit. Voor andere tests kan verwezen worden naar Van de Velde (2009: 320-324).

(11) Er zaten wat je noemt een paar flinke gaten in zijn kennis. ${ }^{13}$

(12) ?? Er zat wat je gekocht had in de boodschappentas.

(13) Vervolgens viel Duisenberg van haar stoel en werd zij uitgescholden door wat later de eigenaresse bleek. ${ }^{14}$

(14) Hij wordt voortdurend uitgescholden door wie/* wat hij vroeger opgeleid heeft.

Hoe moet zo'n TVR nu eigenlijk geanalyseerd worden? Hoe komen deze vrije relatiefzinnen aan hun transparantie? De literatuur, vooral aan forme$\mathrm{le}^{15}$ zijde, bevat verschillende suggesties (zie Schelfhout e.a. 2004 en Van de Velde 2009: 324-328). Sommigen daarvan minimaliseren het onderscheid tussen TVR'en en RVR'en (bijvoorbeeld Grosu 2003 en de niet-Chomskyaanse formele analyse in Yoo 2008), maar anderen zien toch een duidelijk verschil. Veel analyses zijn varianten op het idee dat in een RVR twee syntactische bomen in elkaar geschoven zijn op een plaats waar hun structuur overlapt. Dat komt het best tot uiting in de botanische metafoor van het 'enten' die Van Riemsdijk (2000a, 200ob) gebruikt om een en ander inzichtelijk voor te stellen. In een voorbeeld als (15) is er een nieuwe syntactische structuur 'geënt' op de basisboomstructuur van de eigenlijke zin:

(15) De snelheden waarop alle voorwerpen rond mij geslingerd werden vertraagde in wat leek op een overtreding van de wet van behoud van beweging. ${ }^{16}$

13 http://moeders.nu/faalangst-bij-kinderen-en-jongeren/, bezocht op 2013-03-29.

14 http://www.volkskrant.nl/vk/nl/2664/Nieuws/article/detail/1901259/2011/05/04/Gretta-Duisenberg-veroorzaakt-rumoer-tijdens-dodenherdenking.dhtml, bezocht op 2013-03-29.

15 Bedoeld zijn 'Chomskyaanse' of 'generatieve' benaderingen, maar ik volg hier Haspelmath (2000), die de term 'formeel' verkiest als overkoepelend label.

16 http://www.nderf.org/Dutch/when_time_stood_still_bde.htm, bezocht op 2013-04-03. 
(16) Boom 1: De snelheden waarop alle voorwerpen rond mij geslingerd werden vertraagde in een overtreding van de wet van behoud van beweging.

Boom 2: wat leek op een overtreding van de wet van behoud van beweging

Mijn eigen analyse sluit daarbij aan, in die zin dat die erkent dat er twee aparte structuren in elkaar geschoven zijn, maar ik leg wat meer de nadruk op analogische processen in de diachronie van de constructie. Het idee is dat de TVR een uit de hand gelopen vorm is van een zgn. 'kopbepaling' in de nominale constituent. Wat oorspronkelijk een vrije relatiefzin was, is naar analogie van de steeds drukker gebruikte kavel voor kopbepalingen zélf als een kopbepaling geheranalyseerd. Dergelijke hybride heranalyses vind je ook elders: op precies dezelfde manier zijn voorzetsels als bij, rond etc. als approximatoren in constructies van het type rond de dertig jaar, bij de tien mensen etc. ontstaan (zie Plank 2004, met een analyse die overdraagbaar is op het Nederlands).

Om te begrijpen wat een kopbepaling precies is, moet ik hier eerst iets zeggen over de interne structuur van de nominale constituent. Ook daar zijn verschillende opvattingen over (zie bijvoorbeeld Van der Lubbe 1958; Van Roey 1974; De Schutter 1998, 1999; Broekhuis \& Keizer 2012 voor het Nederlands). Ik ga hier uit van een structuur die trouw is aan wat de oppervlakte te zien geeft. Het syntactisch sjabloon, dat gemakkelijk vertaald kan worden naar een Constructiegrammaticale benadering, staat in (17). De kavels ('slots') staan in een semantische modificatie-relatie en in een syntactische dependentierelatie, in die zin dat de buitenste schil telkens de binnenste in zijn bereik heeft. ${ }^{17}$ De meest opvallende punten zijn (i), een afwijzing van de DP-hypothese van Abney (1987), ten voordele van een klassiek hoofdstatuut voor het nomen, (ii) een weinig gedifferentieerde syntactische structuur van wat zich tussen de determinator en het nomen bevindt (zeg maar het 'middenveld' van de nominale constituent) en (iii) een positie voor kopbepalingen ter linkerzijde van de determinator, hier afgekort als $\mathrm{M}$ (omdat er vaak modale betekenissen mee gemoeid zijn, cf. infra). Verder is het ook belangrijk te beseffen dat de categorieën in het sjabloon kavels zijn, en geen woordsoorten. Dus A staat eigenlijk voor

17 De ruimte is hier te beperkt om in te gaan op de details van de Constructiegrammatica, waarbinnen trouwens nog tal van concurrerende modellen bestaan. De Constructiegrammatica als benadering heeft thans een gevestigd statuut. Voor algemene inleidingen kan verwezen worden naar Hoffmann \& Trousdale (2013), en voor het Nederlands naar Boogaart e.a. (2014, Secties I-III). 
'attributieve bepaling', veeleer dan voor 'adjectief. Die kavel kan dan bezet worden door adjectieven, telwoorden etc. en in het Engels ook nomina en adverbia. $^{18}$

(17) $[\mathrm{NP} \mathrm{M}[\mathrm{D}[\mathrm{A}[\mathrm{N}]]]]$

M: kopbepaling

D: determinator

A: attributieve bepaling

$\mathrm{N}$ : nomen (hoofd)

(18) $\left[\mathrm{NP}_{\mathrm{NP}}\right.$ elf $_{\mathrm{M}}\left[\right.$ de $_{\mathrm{D}}\left[\right.$ grote $_{\mathrm{A}}\left[\right.$ meubelen $\left.\left.\left.\left._{\mathrm{N}}\right]\right]\right]\right]$

De determinatorpositie kan nog verder uitgesplitst worden, binnen een determinatorcomplex, met een predeterminator (Pre-D), bijvoorbeeld $a l$, en een determinator (D), wat een wat complexer sjabloon zou opleveren, zie (19).

(19) $\left[{ }_{N P} M[[\right.$ Pre-D [ D ] ] [ A [ N ] ] ] ]

Wat zijn nu de elementen die de kavel voor de kopbepaling kunnen bezetten? Dat zijn focuspartikels (alleen, zelfs, ook ...), die ook geclusterd kunnen voorkomen (toch ook $k_{s}$ zelfs maar ...) en ook omvangrijker adverbia (misschien, vermoedelijk ...). ${ }^{19}$ Die omvangrijke adverbia behoren tot de categorie der zinsadverbia, die normaal gezien een breed bereik hebben en vaak epistemische noties uitdrukken (zie ook Ramat \& Ricca 1998). Tot slot kan de kavel voor kopbepalingen ook bezet worden door wat Van der Horst (2008: 1896) zinsbrokken noemt (zie ook de 'syntactic amalgams' van

18 In dit syntactische sjabloon zijn de nabepalingen genegeerd. Zie De Schutter (1999) en Van de Velde (2009, hfst.3) voor concurrerende analyses van nabepalingen. Wat de voorbepalingen betreft is het natuurlijk mogelijk om de adjectief-kavel in kleinere perceeltjes onder te verdelen (zie bijvoorbeeld Roose 1956), maar daar zijn ook weer tegenargumenten voor te geven (zie Van de Velde 2009: 46-47, met verwijzing naar onder andere Van der Horst 1995: 165-173). De finale beslissing is voor dit artikel niet van belang.

19 Een beoordelaar merkt op dat het voorkomen van zinsaverbia in de M-kavel aan 'strenge, en vermoedelijk veelal nog onbekende restricties onderhevig [is]'. Restricties die verschillen van die voor focuspartikels. Die beoordelaar geeft ook voorbeelden, die laten zien dat hij/zij gelijk heeft, maar een bespreking van deze restricties vergt een eigen onderzoek, en dat zou te ver voeren. Ik houd het erop dat de zinsadverbia toch vergelijkbaar genoeg zijn met focuspartikels om ze in dezelfde kavel onder te brengen (zie ook Payne \& Huddleston 2002: 436-439 voor het Engels). 
Lakoff 1988). Dat zijn fragmenten van zinnetjes, zoals zeg maar, pak 'm beet, naar verluidt etc. ${ }^{20}$

De interpersoonlijke semantiek van al deze elementen is hierin gelegen dat ze de houding, verwachting of visie van de spreker uitdrukken op de representationele inhoud. Voor de focuspartikels wordt dat geargumenteerd door Nevalainen (1991: 76-83), Harbert (2007: 32) en specifiek voor het Nederlands door De Groot (1949: 96), Van der Lubbe (1958: 149), Foolen (1993: 33), Barbiers (1995: 47, 49, 6o) en Van de Velde (2009, 2010). Voor de andere elementen wordt dat geargumenteerd door Van de Velde (2007, 2012). In een zin als Hij is het jaar nadien van school gestuurd wegens vermoedelijk enkele zedenfeiten heeft de epistemisch-modale bepaling vermoedelijk alleen bereik over enkele zedenfeiten, niet over het van school sturen of over het tijdstip.

De interpersoonlijke semantiek wordt bevestigd door hun syntactische gedrag: ze staan uiterst links, ze liggen buiten het bereik van de negatie, en ze laten zich nauwelijks zelf in focus plaatsen (zie Van de Velde 2009: 161), eigenschappen die symptomatisch zijn voor interpersoonlijke elementen (zie ook Company Company 2006a,b en De Smet \& Verstraete 2006).

In de ordening van kleine focuspartikels over grotere zinsadverbia tot nog omvangrijker zinsbrokken zit een diachronie (Van de Velde 2009, 2010): de omvangrijker types komen diachroon na de kleinere elementjes, en vormen daar een analogische uitbreiding op (zie Van de Velde 2011 voor een gedetailleerd onderzoek naar de verschillende tussenstappen in het Engels, dat zich op dit terrein goed laat vergelijken met het Nederlands). Focuspartikels komen opzetten in het vroegste Nieuwnederlands, via heranalyse van adverbia, terwijl omvangrijker zinsadverbia in de nominale constituent pas aangetroffen worden in de 19de eeuw. Dat al deze elementen tot de nominale constituent behoren, blijkt onder andere hieruit dat ze PP-intern kunnen voorkomen (zie Van de Velde 2009, 2010 voor een volledige analyse en bijkomende tests), wat geillustreerd wordt in (15) en $(21)^{21}$

(20) $\left[{ }_{\mathrm{PP}}\right.$ van $\left[\mathrm{NP}\right.$ zelfs/ook maar/misschien/zeg maar/... ${ }_{\mathrm{M}}\left[\right.$ de $_{\mathrm{D}}\left[\right.$ grote $_{\mathrm{A}}$ [ meubelen $\left.\left.\left.\left.\left.\left._{\mathrm{N}}\right]\right]\right]\right]\right]\right]$

20 Net zoals andere kopbepalingen kunnen de zinsbrokken 'gestapeld', dus in combinatie met elkaar en met andere kopbepalingen voorkomen, bv. met naar verluidt toch wel zware fouten, met toch wel wat je kunt noemen ernstige fouten.

21 Hetzelfde argument wordt ook gebruikt door Payne \& Huddleston (2002) voor het Engels. 
Terug naar de transparante vrije relatiefzinnen nu: TVR'en zijn eigenlijk zinsbrokken die net als zeg maar of naar ik aanneem of ik denk de Mpositie innemen in het sjabloon in (17)-(19), zie (21). ${ }^{22}$ Ze hebben ook een semantiek die zich daar goed mee laat verenigen: ze geven een subjectieve inschatting van de realiteit van de referent (zie ook Zwart 2006).

(21) Vannacht wakker geworden van wat leek op een luchtalarm. ${ }^{23}$ $\left[\mathrm{PP}\right.$ van $\left[\mathrm{NP}\right.$ wat leek $\mathrm{op}_{\mathrm{M}}\left[\right.$ een $_{\mathrm{D}}\left[\right.$ luchtalarm $\left.\left.\left.\left._{\mathrm{N}}\right]\right]\right]\right]$

zeg maar

naar ik aanneem

ik denk

Onder de zinsbrokken die als kopbepaling kunnen functioneren in het Nederlands, vormt de TVR enigszins een uitzondering. In tegenstelling tot het Engels staat de inhoudskern niet altijd rechtsperifeer. In (9), (11), (15) en (21) is dat wel het geval, maar in (13) en (22) niet. $^{24}$

(22) Aan het eind van dit proces is er wat je een schetsontwerp zou kunnen noemen. ${ }^{25}$

(23) $\left[\mathrm{NP}\right.$ wat je... M-deelı $\left[\right.$ een $_{\mathrm{D}}\left[\right.$ schetsontwerp $\left.\left._{\mathrm{N}}\right]\right]$...zou kunnen noe$\operatorname{men}_{\mathrm{M}-\text { deel }_{2}}$ ] ]

Dat komt door de tweepolige structuur van de Nederlandse zin. Het vervoegde werkwoord in de TVR staat op de tweede zinspool, zoals gebruikelijk is in Nederlandse bijzinnen. ${ }^{26}$ Als de inhoudskern een voorzetselconstituent is dan kan die postverbaal gerealiseerd worden door extrapositie (vroeger ook wel PP-over-V genoemd), zoals in (21), maar als die nominaal

22 Het is natuurlijk ook mogelijk de zinsbrok aan te hechten aan de adjectiefgroep in plaats van aan de hele NP. Een geval als [ $\mathrm{PP}$ met [NP die [AP zeg maar bizarre ] [initiatieven ] ] ] staat dan tegenover [ ${ }_{\mathrm{PP}}$ met [NP $_{\mathrm{N}}$ eg maar [ die [ bizarre [ initiatieven ] ] ] ] ], zoals [ ${ }_{\mathrm{PP}}$ met ${ }_{\mathrm{NP}}$ de [AP $_{\mathrm{AP}}$ vermoedelijk laatste] [ bus ] ] ] staat tegenover [pp met [NP vermoedelijk [de [laatste [bus ] ] ] ] ]. 23 http://meuker.tumblr.com/page/2, bezocht op 2013-04-05.

24 Er zijn trouwens ook Engelse TVR'en denkbaar die een niet rechtsperifere inhoudskern hebben (De Smet \& Van de Velde 2013).

25 http://sts.bwk.tue.nl/7s310/, bezocht op 2013-04-05.

26 Ik ga ervan uit dat de lezer vertrouwd is met de woordvolgordeprincipes van de Nederlandse bijzin. Als dat niet het geval is, kan die lezer te rade in Haeseryn e.a. (1997: 1221-1400), Verstraete (2003) of Zwart (2011). 
is, zoals in (22), dan gaat dat in principe niet. ${ }^{27}$ Het Nederlands laat geen extrapositie van nominale constituenten toe (NP-over-V). RVR'en gedragen zich inderdaad volgens deze regels, zie Tabel 1.

Tabel 1 Extrapositiemogelijkheden in reguliere vrije relatiefzinnen

\begin{tabular}{lll}
\hline & Preverbale realisatie & Extrapositie \\
\hline PP & Wat hij voor zijn moeder gekocht had & Wat hij gekocht had voor zijn moeder \\
NP & Wat hij zijn buurman aangedaan had & ${ }^{*}$ Wat hij aangedaan had zijn buurman \\
\hline
\end{tabular}

Als de TVR, in tegenstelling tot de RVR, inderdaad een geval is van heranalyse (door analogie) tot een kopbepaling, dan zou je mogen verwachten dat taalgebruikers waar dat mogelijk, is een discontinue structuur vermijden, op grond van de Eerste wet van Behaghel, die zegt: 'Das oberste Gesetz ist dieses, daß das geistig eng Zusammengehörige auch eng zusammengestellt wird' (Behaghel 1932: 4). Dat is daadwerkelijk ook het geval. Uit onderzoek van De Smet \& Van de Velde (2013) blijkt dat extrapositie van een PP statistisch significant vaker plaatsvindt in TVR'en dan in RVR'en.

Maar wat doen taalgebruikers wanneer de inhoudskern geen PP is, die geëxtraponeerd 'mag' worden, maar een NP, die niet geëxtraponeerd mag worden? Merkwaardigerwijs ziet de taalgebruiker er in zulke gevallen geen been in om de NP alsnog te extraponeren. Een kleine verzameling voorbeelden, die gemakkelijk uitgebreid kan worden:

(24) Het is wat je zou kunnen noemen een diepteonderzoek $(\ldots)^{28}$

(25) Er zijn ook wat je zou kunnen noemen relationele vormen van meditatie. $^{29}$

(26) Dit is wat je noemt een sprookjeshuwelijk. ${ }^{30}$

(27) In deze verzameling eerder gepubliceerde artikelen en redevoeringen van wat vaak genoemd wordt de enige intellectueel in de Nederlandse politiek haalt Frits Bolkestein veel overhoop. ${ }^{31}$

(28) Dit zijn wat genoemd wordt de medebewindstaken. ${ }^{32}$

27 Extrapositie gaat bij de ene PP al gemakkelijker dan bij de andere. Hoe zwaarder de PP, hoe gemakkelijker. Het is niet eenvoudig PPs te vinden die helemaal geen extrapositie toelaten.

28 http://www.filmsalon.be/abnormalbeauty.html, bezocht op 2013-04-05.

$29 \mathrm{http} / / /$ levenindemaalstroom.drupalgardens.com/blog/wat-onze-praktijk-3, bezocht op 2013-04-05.

30 http://www.froot.nl/posttype/froot/dit-is-wat-je-noemt-een-sprookjeshuwelijk/, bezocht op 201304-05.

31 http://www.boekenstrijd.nl/index.php?option=com_search\&Itemid=99999999\&searchword=filosofie\&searchphrase=exact\&ordering=newest\&limit=5\&limitstart=5, bezocht op 2013-04-05

32 http://www.west-vlaanderen.be/provincie/beleid_bestuur/provinciebestuur/Pages/opdracht.aspx, bezocht op 2013-04-05. 
Extrapositie van een nominaal complement is niet altijd ongrammaticaal geweest in de loop van de geschiedenis van het Nederlands. In het Middelnederlands komt die constructie nog geregeld voor en ze kan aangetroffen worden tot in de 18de eeuw, zie (29). Maar zoals Van der Horst (2008: 1051) opmerkt, is het gebruik van dat soort extraposities een aflopende zaak, en al in het vroegste Nieuwnederlands een verouderde constructie, te oordelen naar hun geringe frequentie (zie ook Coussé 2009).

(29) (Leamina) Die eevenwel niet ontkenden de gemeenschap die zy met Philibert hield (18de eeuw, Van der Horst 2008: 1604)

Die algemene afname van geëxtraponeerde nominale constituenten gaat in tegen de trend die we zien in TVR'en. Daar is extrapositie juist in opmars. De volgende tabel, gebaseerd op De Smet \& Van de Velde (2013) is gebaseerd op 136 treffers van vrije relatiefzinnen ${ }^{33}$ waarvoor sterke aanwijzingen zijn dat ze transparant zijn. ${ }^{34}$

Tabel 2 'Ongeoorloofde' extrapositie (van niet-PPs) in TVR'en

\begin{tabular}{llll}
\hline & $\begin{array}{l}\text { Aantal ondubbel- } \\
\text { zinnige TVR'en }\end{array}$ & $\begin{array}{l}\text { 'Ongeoorloofde' } \\
\text { extrapositie }\end{array}$ & $\begin{array}{l}\text { Percentage TVR'en met } \\
\text { 'ongeoorloofde' extrapositie }\end{array}$ \\
\hline 17de eeuw & 2 & 0 & 0,0 \\
18de eeuw & 6 & 1 & 16,6 \\
19de eeuw & 69 & 24 & 34,8 \\
20ste eeuw & 59 & 22 & 37,3 \\
\hline
\end{tabular}

Zoals uit de tabel blijkt, stijgt het gebruik van de ongeoorloofde extrapositie, in een periode waarin het Nederlands de constructie elders nauwelijks

$33 \mathrm{Er}$ is gezocht naar vrije relatiefzinnen van de vorm 'relatiefpronomen + een spanne van maximaal vijf woorden + een niet-preteritale vorm van het werkwoord noemen' in het citatencorpus van het WNT. Voor een verdediging van het gebruik van het citatencorpus van grote historische woordenboeken als corpus, zie Mair (2004: 123-125).

34 Zulke aanwijzingen zijn bijvoorbeeld congruentie met het rompzinwerkwoord als de vrije relatiefzin het subject is of selectierestricties van het rompzinwerkwoord etc. Niettemin blijft er sowieso een aanzienlijk fonds over van vrije relatiefzinnen waarbij het moeilijk te beoordelen is of ze transparant zijn (zie Van de Velde 2009: 334-335 voor details) 
nog toelaat. ${ }^{35}$ Het gebruik van geëxtraponeerde nominale constituenten in TVR'en is met andere woorden een heropstanding van een stervende, of althans schijndode constructie. De toename is gemotiveerd door de analogische aantrekking van een andere constructie, namelijk de kopbepaling.

\subsection{De wat betreft-constructie}

Een tweede geval van een syntactische feniks, die uit zijn as herrijst, is eigenlijk analoog aan wat we net gezien hebben bij de TVR. Het gaat om de topic-markeerder-constructie met wat betreft. ${ }^{36}$

(30) Wat betreft de veranderingen die zich in het ruimere beleidskader hebben voorgedaan, moeten vooral de strategieën van Lissabon en Göteborg en de jongste uitbreiding van de EU worden genoemd. ${ }^{37}$

Diachroon hebben we hier evident eveneens met een vrije relatiefzin te maken, waarin het direct object geëxtraponeerd is. De niet-geëxtraponeerde tegenhanger is ook mogelijk:

(31) Wat de veranderingen betreft gaat het om bepalingen met betrekking tot de MML $(\ldots)^{38}$

35 De cijfers zijn weliswaar te beperkt om de statistische betrouwbaarheid na te gaan. In theorie is het mogelijk een z-test op de proporties uit te voeren (zie Butler 1985: 92-95 voor de algemene achtergrond en Van de Velde 2004: 66-69 voor een toepassing), maar het product van ofwel de proportie van de som van het aantal 'ongeoorloofde extraposities' over de som van het aantal 'ondubbelzinnige TVR'en' ofwel 1 min deze proportie enerzijds en de kleinste van de twee steekproefgroottes - in dit geval dus het aantal ondubbelzinnige TVR'en - anderzijds, moet minstens vijf zijn, en dat is niet het geval voor de vergelijking van de ${ }_{17}$ de met de 18 de eeuw en voor de vergelijking van de $18 \mathrm{de}$ eeuw met de 19de eeuw. (Het verschil is wel significant voor de proporties in de 19de en de 20ste eeuw $(\mathrm{p}<0,01)$.) Maar: dat we überhaupt een stijging zien in een diachrone schijf van vierhonderd jaar waarin extrapositie van NPs elders steeds zeldzamer wordt, is spectaculair, ook zonder significantietest. Eigenlijk verwacht je in de 19de en de 2oste eeuw, en misschien ook de 18de eeuw (zie echter (29)) ook eenvoudigweg $0 \%$ onder de nulhypothese dat ongeoorloofde extrapositie niet wordt toegepast.

36 Een beoordelaar merkt terecht op dat de functie van wat ... betreft niet beperkt is tot topicmarkeerder. In combinatie met een obliek persoonlijk voornaamwoord (wat mij betreft) drukt het de attitude van de met het pronomen aangeduide persoon aan. De constructie met een pronomen blijft hier buiten beschouwing omdat die zich lastiger laat extraponeren. Helemaal uitgesloten is zo'n patroon trouwens zeker niet: Wat betreft mij blijft dit topic open (http://forum.tribalwars.nl/showthread.php?11680o-Ik-zwaai-uit/page3, bezocht op 2014-07-08).

37 http://eur-lex.europa.eu/LexUriServ/LexUriServ.do?uri=CELEX:52005DCoo84:NL:NOT, bezocht op 2013-04-08.

$3^{8}$ http://agriculture.wallonie.be/apps/spip_wolwin/IMG/pdf/NOTICE2013voletı_NL.pdf, bezocht op 2013-04-08. 
Extrapositie is moeilijker of zelfs ongrammaticaal als het direct object een niet-gemodificeerd persoonlijk voornaamwoord is (?? wat betreft mij, ?? wat betreft hem ...), maar is verder aan weinig beperkingen gebonden. De diachronie van de constructie is goed te volgen in het WNT (s.v. betreffen). Het werkwoord betreffen had oorspronkelijk een concrete betekenis 'raken', en is later ook overdrachtelijk gebruikt als 'ergens over handelen'. Eenzelfde betekenisontwikkeling heeft ook 'ergens op slaan' doorgemaakt. De uitdrukking wat X betreft betekent dan 'wat X aangaat'. In ouder Nederlands wordt nogal eens het tegenwoordig deelwoord gebruikt, maar later is de constructie met de vrije relatiefzin gebruikelijk geworden. Het WNT geeft onder het lemma betreffen 19de-eeuwse voorbeelden, maar de constructie is al eerder geattesteerd. Als we het hele citatencorpus van het WNT doorzoeken, dan hebben we een vroeg voorbeeld uit de 17de eeuw, zie (32), al hebben we hier nog niet echt met de zuivere topic-markeerder te maken, maar met een relatiefzin na al(les). ${ }^{39}$ Voor het onderzoek naar extrapositie in dit soort (half-)vrije relatiefzinnen is deze context niettemin interessant, omdat ook hier extrapositie mogelijk is in het hedendaags Nederlands, zie (33).

(32) De ingezeetenen der voornoemde Landschappen ook de geene, die, uit andre oorden, de zyde der Staaten van de onderhandelende gewesten gevolght hebben, te doen achten, belangende 't recht van Verlaaten goedt, de erffenissen, het in- en uitvoeren van allerley waaren en koopmanschappen, samt alles wat den koophandel op Vrankryk betreft, als inboorlingen van dien (1645, WNT, s.v. Verlaten (I)).

(33) Om kort te zijn, de eigenaar is verantwoordelijk voor alles wat betreft de structurele werken en het 'grote onderhoud' gerelateerd aan de instandhouding van het gebouw. ${ }^{40}$

De vraag is nu of we hier eenzelfde 'heropstanding' zien van de verouderde constructie van extrapositie van het direct object als bij de TVR in \$3.1. Dat blijkt inderdaad het geval te zijn: extrapositie wordt frequenter, al zit het

39 Er is gezocht naar treffers die beantwoorden aan het patroon ' wat + maximaal vijf woorden + een niet-preteritale vorm van het werkwoord betreffen'. Daarmee missen we mogelijk relevante patronen die met het relativum hetgeen starten, maar een extra zoekopdracht naar dit soort patronen heeft slechts één relevante treffer opgeleverd uit 1944, en tast het diachrone beeld in Figuur 1 dus niet aan.

40 http://www.immoweb.be/nl/te-huur/artikel/huurder-/-verhuurder:-wie-doet-wat-en-wie-betaalt-wat-.htm?mycurrent_section=rent\&artid=4745, bezocht 2013-04-08. 
effect met de onderzochte, beperkte WNT-dataset eigenlijk alleen in de 2oste eeuw. ${ }^{41}$ Dat is te zien in de mozaïekplot in Figuur 1. De breedtes van de balkjes geven de absolute aantallen observaties weer. De donkere cellen zijn die welke het meeste bijdragen tot het effect (zie Zeileis e.a. 2007). ${ }^{42}$

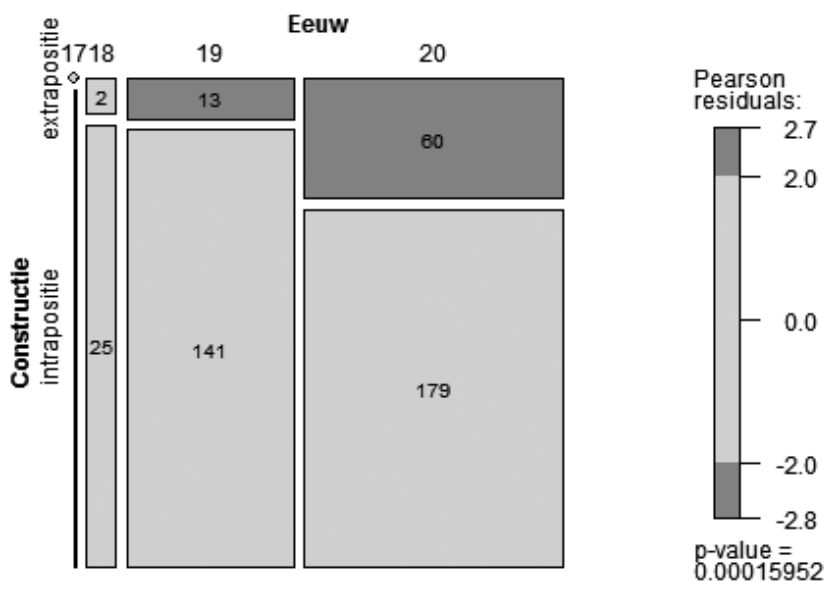

Figuur 1 Extrapositie van het direct object in de wat ... betreft-constructie in het citatencorpus van het WNT

Om na te gaan of het verschil tussen de 19de en de 2oste eeuw standhoudt, is de verdeling tussen intrapositie en extrapositie nog eens nagegaan in een ander corpus: een steekproef van 500 voorbeelden uit de 19de en de 20 ste eeuw van het Corpus Historische kranten in Nederland (http://kranten.delpher.nl/). ${ }^{43}$ We zien daar hetzelfde beeld, zij het minder uitgesproken: de

41 Hier zijn de gevallen met een persoonlijk voornaamwoord genegeerd, omdat die principieel niet goed te gebruiken zijn in de geëxtraponeerde variant. Het verschil tussen de periodes is statistisch significant: Fisher Exact Test (tweezijdig): $\mathrm{p}<0,0001$, en er is een correlatie tussen de tijdsvariabele en de toename van extrapositie: Kendall tau: 0,21). De statistische analyses en de plot commando's in dit artikel zijn uitgevoerd met het software pakket R. (R Core Team. 2012. $R$ : A language and environment for statistical computing. Vienna. http://www.R-project.org). Er is daarbinnen gebruik gemaakt van het pakket $v c d$ (Meyer e.a. 2006, 2013, Zeileis e.a. 2007) en het pakket plotrix (Lemon 2006).

42 De p-waarde in de grafiek is die van de Pearson chi-kwadraattest, maar door de kleine aantallen in de vroege eeuwen is het beter om hier met een Fisher Exact Test te werken (zie Voetnoot 41).

43 De zoekopdracht is gedraaid op een subsectie van ongeveer 185 miljoen woorden, waarvan de OCRkwaliteit voldoende groot is. Dezelfde subsectie is ook gebruikt voor het onderzoek in $§ 3.4$, infra. 
toename van extrapositie gaat van $8 \%$ naar $25 \%$ in de WNT-dataset, en van $21 \%$ naar $29 \%$ in het krantencorpus. Ongeveer de helft zo groot dus. ${ }^{44}$

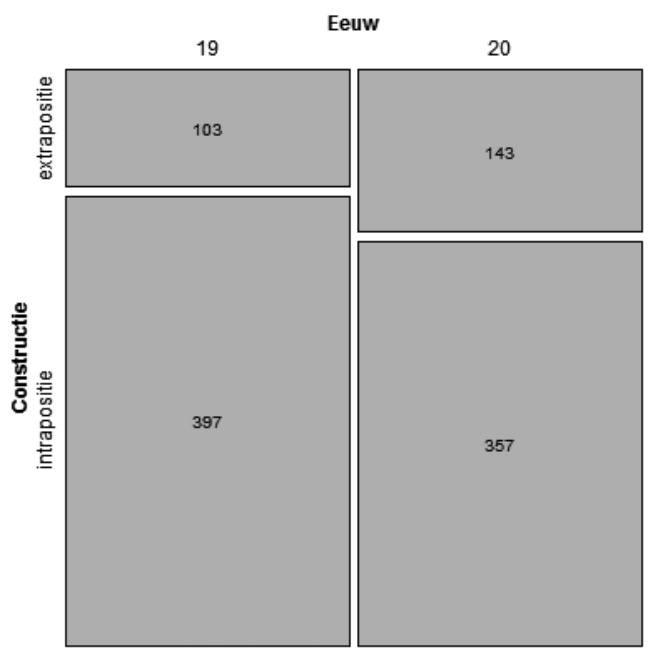

Figuur 2 Extrapositie van het direct object in de wat ... betreft-constructie in het Corpus historische kranten van Nederland (steekproef)

Samengevat: de toename in extrapositie is niet heel groot, maar net zoals bij de TVR'en geldt ook voor wat ... betreft dat het überhaupt merkwaardig is dat er in de 2oste eeuw significant meer extrapositie voorkomt dan in vroeger eeuwen.

Net zoals bij de TVR is de oorzaak van de opflakkering van het 'verouderde' extrapositiepatroon in de wat betreft-constructie de analogische aantrekking van een andere constructie, die als doel van de heranalyse (door analogie) functioneert. Het patroon wat betreft heeft de functie van

44 De verdeling is weliswaar significant (Pearson's Chi-kwadraat met Yates' continuïteitscorrectie $\mathrm{p}<0,01$ ), maar de effectgrootte is klein (Cramér's $\mathrm{V}=0,09$ ). Voor de 18de eeuw konden geen 500 voorbeelden gevonden worden: de subsectie van het krantencorpus waar naar gekeken is, leverde slechts 65 voorbeelden op. Een analyse van die voorbeelden laat zien dat die net onder het niveau van de 20 ste eeuw zitten wat extrapositie betreft $(28 \%)$. Van een lineaire afname is dus geen sprake. Maar dat je een soort U-patroon krijgt, is op zichzelf niet onlogisch: die kan het gevolg zijn van een diachroon toenemende intolerantie jegens nominale extrapositie in het algemeen enerzijds, en een diachrone toename in nominale extrapositie in wat ... betreft constructies anderzijds. Het is wellicht het verstandigst te kijken naar de veranderingen van de 19de tot de 2oste eeuw, en geen uitspraken te doen over de diachrone tendensen in de eeuwen voordien. 
een complexe prepositie, en preposities staan in meerderheid integraal vóór hun complement. ${ }^{45}$

(34) $\left[\mathrm{PP}\right.$ wat betreft $\mathrm{P}_{\mathrm{PP}}\left[\right.$ de $_{\mathrm{D}}\left[\right.$ veranderingen $\left.\left.\left._{\mathrm{N}}\right]\right]\right]$

Je zou je natuurlijk de vraag kunnen stellen of we hier niet gewoon te maken hebben met een disruptief effect van heranalyse: de streng wat betreft wordt een prepositie, en verliest daardoor zijn compositionele structuur, en doet dan helemaal niet meer mee met de beperkingen die gelden voor het wel nog transparante zinnetje wat ... betreft. Met andere woorden: hebben we hier daadwerkelijk te maken met een heropleving van een oud patroon, of levert de heranalyse van vrije relatiefzin tot een complexe prepositie toevallig hetzelfde patroon op als iets wat vroeger in de taal bestond? Een argument dat het in dit geval toch gaat om de uitbuiting van een verouderd patroon, is dat de verandering zich niet voordoet bij de semantisch verwante constructie wat ... aangaat. Aangaan is een combinatie van een scheidbaar partikel en een werkwoord (aan + gaan), en extrapositie van het direct object is in dat geval een grovere overtreding, omdat het partikel aan zelf binnen de tang blijft. Het patroon waarbij het scheidbare partikel aan niet en het direct object wel na de tweede zinspool staat, is weliswaar niet onmogelijk in oudere stadia van het Nederlands, zie (35) met het werkwoord aanroepen, maar bij aangaan (zie MNW s.v. aengaen) zien we vaak dat aan buiten de tang geplaatst wordt, zoals in (36)(37). In beide zinnen blijft het (pronominaal) object weliswaar binnen de tang, maar dat is voor pronomina sowieso de voorkeurspositie, ook bij betreffen. In (36) is het subject (die avond) mee geëxtraponeerd.

(35) waer om men hier aenroepen sal die souen ordenen der heiligen (15de eeuw, Van der Horst 2008: 625)

'waarom men hier de zeven ordes der heiligen moet aanroepen'

(36) Ne ware dat hem ghinc an die avont, het ware al ten ende comen (late 13de, vroege 14de eeuw, MNW, s.v. aengaen) 'tenzij dat de avond hem zou overvallen, zou het allemaal ten einde gekomen zijn'

(37) Mi wondert wat hem ginc ane te segghene van den Zwane (14de eeuw, MNW, s.v. aengaen) 
'Ik zou wel eens willen weten wat hem overviel, om te vertellen over de zwaan'

Extrapositie van het direct object bij wat ... betreft zou dus gemakkelijker kunnen zijn omdat die ook voorkwam buiten de context van de complexe prepositie, zie (38). Dat soort zinnen laat zich met aangaan niet gauw aantreffen. Anders gezegd: het partikel aan speelt een storende rol in een eenvoudige toepassing van een extrapositieregel. Het manifeste grammaticaliteitsverschil tussen wat betreft $X$ en *wat aangaat $X$ is anders niet zo eenvoudig te verklaren.

(38) Dat het ... betreft een zaak van koophandel (...) (1892, WNT s.v. zaak)

(39) ?? Dat het aangaat een zaak van koophandel

\subsection{Accusativus cum infinitivo en nominativus cum infinitivo}

Het Nederlands heeft een constructie waarbij een zinsdeel dat als onderwerp in een completiefzin (dat-zin) hoort, als lijdend voorwerp in de rompzin staat en waarin het werkwoord in de infinitief staat. De constructie in kwestie staat bekend onder verschillende namen: (subject-to-object) raising, accusativus cum infinitivo (ACI), zinsverstrengeling of zinsvervlechting (al verstaat niet iedereen exact hetzelfde onder al deze termen). Voorbeelden (40) en (41) geven een idee om wat voor soort zinnen het gaat. Soms wordt een onderscheid gemaakt tussen gevallen als (40), waarin het vervoegde werkwoord (hier dus: zagen) een nominaal direct object kan hebben en gevallen als (41), waarin dat niet het geval is. Voorstanders van dat onderscheid beschouwen vaak alleen (41) als echte 'raising' en spreken in het andere geval (40) van '(object) control'. Ik zal dat terminologische onderscheid hier niet hanteren, maar in navolging van onder andere Duinhoven (1991), Fischer (1994), Noël \& Colleman (2009, 2010) en Colleman \& Noël $(2009,2012)$ in dit artikel overkoepelend spreken van de ACI-constructie (en 'raising'), zonder te ontkennen dat daarin verder wel subtypes onderscheiden kunnen worden. Dit artikel is vooral geïnteresseerd in het type ACI met een lange infinitief. De combinatie van een verbum sentiendi en een naakte infinitief, zoals in (40) blijft hier buiten beschouwing. 
(40) We zagen hem in de schaduw van de piramides van Gizeh verwikkeld raken in een woordenwisseling tussen twee handelaars ${ }^{46}$

(41) Dit indexcijfer achten we een indicatie te zijn voor het moderniseringsproces ${ }^{47}$

Het Nederlands heeft niet veel met het type ACI in (41). De constructie is een tijdlang populair geweest in geschreven taal, met name in het Middelnederlands en het Vroegnieuwnederlands, als ontlening uit het Latijn (zie Fischer 1994 en Noël \& Colleman 2010 en de aldaar geciteerde literatuur). ${ }^{48}$ Tegenwoordig is de constructie verouderd. Een voorbeeld als (41) is vrij zeldzaam, en hoogst schrijftalig. Volgens Hoeksema (1998: 162) is de ACI zelfs dood.

Het Nederlands heeft een verwante constructie, geillustreerd in (42). Deze constructie heet ook wel de nominativus cum infinitivo (NCI) of wordt beschouwd als een subtype van subject-to-subject raising (Van der Auwera \& Noël 2011).

(42) Gegevens die door de klant zijn aangeleverd, worden geacht in regel te zijn met de geldende wetten op het auteursrecht en de overige intellectuele eigendomsrechten. ${ }^{49}$

Op het eerste gezicht lijkt deze NCI gewoon de passieve tegenhanger te zijn van de ACI, maar dat is niet zo. Noël \& Colleman (2009, 2010) en Colleman \& Noël (2009, 2012) maken aannemelijk dat het om een aparte constructie gaat. Een van hun argumenten is dat de NCI heel wat productiever is dan de ACI, wat op zijn minst vreemd is als het de passieve versie van de ACI zou zijn: passieve zinnen zijn in de regel nu juist minder frequent dan hun actieve tegenhangers. Bovendien hebben veel NCI's überhaupt geen actieve tegenhanger.

De NCI-constructie valt eigenlijk uiteen in verschillende semantische subtypes. Allereerst zijn er gevallen zoals (43), waarin een passief verbum cogitandi (occasioneel ook een verbum declarandi), letterlijk opgevat kan worden. Het gaat hier om 'descriptieve' NCI's, in de woorden van Noël \& Colleman. In dergelijke voorbeelden is het NCI-werkwoord niet weglaat-

46 http://www.humo.be/tv-reviews/208451/tv-review-dr-livingstone-op-vier, bezocht op 201304-09.

47 http://arno.uvt.nl/show.cgi?fid=105737, bezocht op 2013-04-09.

48 Het is niet duidelijk of het om een echte ontlening gaat, of dat het Latijn alleen maar een faciliterende rol heeft gespeeld.

49 http://quoted.be/voorwaarden/, bezocht op 2013-04-10. 
baar zonder dat betekenis aangetast wordt ( ${ }^{\#}$ Donkere materie bestaat om $(\ldots))$.

(43) Donkere materie wordt verondersteld te bestaan om de waargenomen baanbeweging van verre sterren en afgeplatte spiraalvormige sterrenstelsels (zoals ons eigen Melkwegstelsel) te verklaren op een wijze die zowel consistent is met de zwaartekrachttheorie als met de relativiteitstheorie. ${ }^{50}$

Zo'n letterlijke lezing ligt minder voor de hand in de volgende twee voorbeelden.

(44) Alle leerlingen worden verondersteld mee te gaan. Enkel een tijdig binnengebracht doktersbewijs kan de afwezigheid wettigen. ${ }^{51}$

(45) Het massief wordt verondersteld ooit deel te zijn geweest van het paleocontinent Avalonia ${ }^{52}$

In beide gevallen is de letterlijke betekenis van het werkwoord veronderstellen naar de achtergrond getreden, en verliest de zin alleen wat modale kleuring als het NCI-werkwoord weggelaten wordt (Alle leerlingen gaan mee (...); het massief is ooit deel geweest (...)). Het terugtreden van de letterlijke betekenis is het duidelijkst in (44). In de meest voor de hand liggende lezing wordt er niets verondersteld, maar moeten de leerlingen meegaan. Het opnemen van deze passage in een reglement suggereert in feite dat een al te gemakkelijke 'veronderstelling' juist niet gewettigd is. In (45) is het à la limite mogelijk vol te houden dat 'veronderstellen' letterlijk opgevat moet worden, maar het is toch moeilijk om het handelend voorwerp expliciet te maken. Voorbeeld (44) en voorbeeld (45) zijn twee aparte

$5^{0}$ http://nl.wikipedia.org/wiki/Donkere_materie, bezocht op 2013-04-10. Er is over gewaakt dat het hier niet om een evidente vertaalinterferentie uit het overeenkomstige Engelse Wikipediaartikel gaat. Niettemin zijn gevallen als (43), en ook (46), niet voor alle sprekers acceptabel. Een reviewer vindt zulke voorbeelden 'vrijwel onacceptabel'. Dat vind ik zelf een nogal hardvochtig oordeel. Veel hangt misschien ook af van het type taalgebruiker: uit het onderzoek van Dąbrowska (2012) weten we dat sommige sprekers syntactische patronen gemakkelijker generaliseren dan andere, die een meer lexicale strategie hanteren. Zelf heb ik bijvoorbeeld de grootste moeite met voorbeelden (56)-(61), terwijl het helemaal niet zo moeilijk is daar voorbeelden van te vinden. $5^{1}$ http://www.sg-noord.be/shim/shim_home/index.php?option=com_content\&view=article\&id=79\&Itemid=81, bezocht op 2013-04-10.

$5^{2}$ http://nl.wikipedia.org/wiki/Londen-Brabantmassief, bezocht op 2013-04-10. Het gaat hier niet om een vertaalinterferentie uit het overeenkomstige Engelse Wikipedia-artikel. Daar staat: The London-Brabant Massif is part of the former microcontinent Avalonia. 
subtypes van de NCI, die respectievelijk een deontisch-modale betekenis uitdrukken en een evidentiële of epistemisch-modale betekenis. ${ }^{53}$ Noël \& Colleman (2009) argumenteren dat de Nederlandse NCI een (licht-)gegrammaticaliseerde constructie is voor het uitdrukken van dit soort modale betekenissen, waarbij de oorspronkelijke lexicale betekenis van de verba declarandi en cogitandi die in de constructie voorkomen, verbleekt is, en waarbij de infinitief weer voluit op de voorgrond treedt. Dat terugtrekken naar de achtergrond is een heel normaal proces in grammaticalisatie en wordt door sommigen zelfs gezien als het wezenlijke aspect ervan (Van de Velde 2009: 144; Boye \& Harder 2012).

Het evidentiële/epistemisch-modale subtype is minder frequent dan het deontisch-modale type in het Nederlands, en laat ook maar een vrij beperkt setje werkwoorden toe (Noël \& Colleman 2009: 171), al lijkt er, mogelijk onder invloed van het Engels, af en toe toch wat meer mogelijk. Het is vooralsnog niet duidelijk of we van een echte recente aanwas mogen spreken. Frequent zijn voorbeelden zoals (46) in ieder geval niet.

(46) Dit stuk van de film wordt gefluisterd te zijn geschreven door een geile Tim Burton. ${ }^{54}$

De piek van de Nederlandse NCI ligt in de 18de eeuw (Noël \& Colleman 2009), maar de constructie wordt nog steeds gebruikt, hoewel de ondersteunende ACI met verba declarandi en cogitandi al nagenoeg helemaal weg is. Waarom houdt de NCI het beter uit in het Nederlands dan de ACI? Meer zelfs, de NCI is in het Middelnederlands niet zo frequent als de ACI (Fischer 1994), maar heeft de ACI in de loop van het Nieuwnederlands ingehaald (zie Noël \& Colleman 2010). De NCI is met andere woorden in de loop van het Nieuwnederlands een syntactische feniks, die ingaat tegen de algemene neerwaartse trend van 'raising' met (lange) infinitieven. Hoe komt dat? Het antwoord ligt in de functie van de NCI. Zoals Duinhoven (1991: 425) en Colleman \& Noël (2009, 2012) laten zien, is de NCI analoog

53 Gezien de notoir vage grens tussen evidentialiteit en epistemische modaliteit (zie b.v. Timberlake 2007) maak ik geen onderscheid tussen beide types betekenissen in NCI's. Noël \& Colleman (2009) doen dat wel, al zijn ze enigszins onduidelijk over de relatie tussen (i) het evidentiële subtype, (ii) het epistemisch-modale subtype en (iii) het deontische subtype.

54 http://ikbenhiernietgraag.wordpress.com/category/fantasie/, bezocht op 2013-04-10. 
aan een hulpwerkwoord. ${ }^{55}$ Dat geldt zowel voor de evidentiële gevallen in (45) (zie (47)) als voor de deontische gevallen in (44) (zie (48)). ${ }^{56}$

$\begin{aligned} \text { Hij } & \begin{array}{l}\text { dunkt me } \\ \text { schijnt } \\ \text { heet }\end{array} \\ & \text { zordt gezegd }(=\mathrm{NCI})^{57} \\ \text { Hij } & \text { hoort } \\ & \text { wordt geacht }(=\mathrm{NCI})\end{aligned}$

De ACI heeft deze analogische ondersteuning niet. Het is precies het passieve karakter van de NCI dat toelaat om het subject van de beknopte bijzin omhoog te halen in getopicaliseerde positie en tegelijkertijd de agens van de verba declarandi en cogitandi onuitgedrukt te laten (zie ook Colleman \& Noël 2009: 399$).{ }^{58}$

Interessant is verder dat de ACI beter standhoudt in relatiefzinnen. Die vaststelling komt van Zajicek (1970), en is nadien aangehaald in Duinhoven (1991: 411), Fischer (1994: 115-118), Colleman \& Noël (2009: 389-390, 2012: 6, 12-13) en Van der Auwera \& Noël (2011: 22). Volgens Fischer (1994: 118) is dat hieraan te wijten dat het subject van de beknopte bijzin niet tussen het vervoegde werkwoord en de infinitief in staat, maar net zoals bij het onderwerp van de NCI-constructie, getopicaliseerd is, en zodoende minder opvalt als oneigenlijke constructie. Dat kan wel zo zijn in sommige gevallen, maar dat is toch niet het hele verhaal. Als we kijken naar de voorbeelden die Zajicek geeft, dan blijkt het in heel wat gevallen om een patroon te gaan dat al hogerop ter sprake is gekomen, namelijk de TVR. Enkele voorbeelden:

(49) Hij stapte in wat hij meende de bus naar Oegstgeest te zijn (Zajicek 1970: 207)

55 Inclusief zgn. koppelwerkwoorden zoals dunken, schïnen, heten, lijken en blijken die uitgebreid kunnen worden met te zijn, en daarom ook als hulpwerkwoord beschouwd kunnen worden, in plaats van als koppelwerkwoord.

56 Als de analogie zich ook uitstrekt over de combinaties met de korte infinitief dan kan voor de evidentiële gevallen ook zou en voor de deontologische gevallen ook moet genoemd worden als analoge attractor. In negatief-polaire contexten is voor de deontologische gevallen ook nog hoeven te noemen als analogische attractor.

57 De evidentiële NCI met zeggen is met name in de 19de eeuw vrij populair geweest (Colleman \& Noël 2009).

$5^{8}$ Ik ga hier niet in op de oorzaak van de latere afname van de NCI in het Nederlands. Zie daarvoor Colleman \& Noël (2012), die daar enkele plausibele verklaringen voor opwerpen. 
(50) Ik gaf de portier wat ik meende een tientje te zijn (Zajicek 1970: 207)

(51) Hij trok zijn lippen op tot wat hij meende een glimlach te zijn (Zajicek 1970: 207)

De oorzaak van de hardnekkigheid van de ACI (en de NCI, zie verderop) in de TVR heeft opnieuw te maken met zijn evidentiële/epistemische functie. De ACI's in (49)-(51) zijn geheranalyseerde kopbepalingen, die dan wel telkens gesplitst zijn over twee delen. ${ }^{59}\left(5^{2}\right)$ loopt met andere woorden parallel met (53), naar analogie van (22), supra.

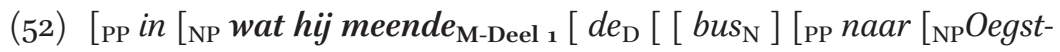

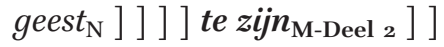

(53) $\left[\mathrm{PP}\right.$ in $\left[\mathrm{NP}_{\text {wat je }}\right.$ M-Deel $_{\mathbf{1}}\left[\right.$ de $_{\mathrm{D}}\left[\left[\right.\right.$ bus $\left._{\mathrm{N}}\right]\left[\mathrm{PP}\right.$ naar $\left[{ }_{\mathrm{NP}}\right.$ Oegstgeest $\left.\left.\left.\left.\mathrm{N}_{\mathrm{N}}\right]\right]\right]\right]$ zou kunnen noemen ${ }_{\mathrm{M}-\text { Deel } 2}$ ]

Ook de NCI kan in deze functie verschijnen:

(54) Ajax zit dus nu met een actieve voorzitter die in het geniep opnamen maakt van wat geacht werd een privé-gesprek te zijn ${ }^{60}$

(55) Een andere opgraving vlakbij Motala haalde in 2010 al het wereldnieuws door de vondst van wat verondersteld werd een dildo uit de Steentijd te zijn. ${ }^{61}$

Als het klopt dat (49) een kopbepaling bevat, en daarom een oude constructie als de ACI in stand houdt, dan mag je, op grond van wat we in §3.1 gezien hebben, verwachten dat ook hier de taalgebruiker geneigd kan zijn om de integrale kopbepaling vóór de determinator te manoeuvreren. Dat kan die taalgebruiker bereiken door ook nog eens extrapositie van het 'geraisde' object toe te passen. Dat is op zichzelf een nogal gewaagd manoeuvre, omdat nu maar liefst twee verouderde constructies tegelijk worden toegepast: ACI en extrapositie. Toch komt dat soort constructies ook echt voor:

59 De nabepaling naar Oegstgeest is in de representatie in (52) en (53) diep aangehecht, binnen het bereik van de determinator. Er zijn alternatieve ontledingen (Van de Velde 2009, 2012). De beslissing is voor de analyse in dit artikel niet relevant.

60 http://forum.fok.nl/topic/1630850/6/25, bezocht op 2013-04-10.

61 http://archeologieonline.nl/nieuws/archeologen-ontdekken-menselijke-schedels-op-stakenin-zweden, bezocht op 2013-04-10. 
(56) Op 4 januari 2013 bij Playmasters.co een bestelling geplaatst naar wat ik dacht te zijn een 10 inch samsung tablet. ${ }^{62}$

En het volgende geval is een analoog type met NCI:

(57) De multiculturele zeepbel is al lang geleden gebarsten toen Pim Fortuyn werd vermoord en toen Theo van Gogh werd vermoord, beide omdat zij hun mening gaven in wat werd verondersteld te zijn één van 's-werelds meest toonaangevende vrijzinnige democratieën. ${ }^{63}$

Maar zowel voor de TVR met ACI als met NCI is er een andere, nog drastischere strategie, die aantoont dat de taalgebruiker rechtsperifere inhoudskernen verkiest. Die strategie wordt geillustreerd in (58)-(61). In al deze voorbeelden ontbreekt een lange infinitief te zijn. De op het eerste gezicht moeilijk verklaarbare afwezigheid daarvan heeft te maken met het statuut als kopbepaling (zie ook Van de Velde 2009: 330-331). Door het semantisch nogal lege te zijn te schrappen komt de taalgebruiker handig uit op een niet-discontinue kopbepaling.

(58) (...) maar gewoon een van Google geplukt 3d-plaatje van wat ik vermoed een enthousiaste fan (...). (Van de Velde 2009: 330)

(59) De modeontwerper werd afgelopen dinsdag in het Broward General Medical Centre in Fort Lauderdale opgenomen met wat werd gedacht een longontsteking. ${ }^{64}$

(6o) Op 30 oktober 1667 begaven Schout en Heemraden van het gerecht Raven zich naar een wat vermoed wordt een daggelderhuisje. ${ }^{65}$

(61) foto's van wat verondersteld wordt de agoo met mogelijk nieuwe Zeiss $16-35 \mathrm{~mm}^{\text {lens }}{ }^{66}$

62 https://www.klachtenkompas.nl/playmastersco/gen-terugbetaling-na-annulering, bezocht op 2013-04-15.

$63 \mathrm{http} / / /$ www.vrijspreker.nl/wp/2010/o2/de-waarheid-zal-u-bevrijden/, bezocht op 2013-04-15. 64 http://glamour.blog.nl/famous/2010/01/14/modetycoon-edgar-vos-78-overleden, bezocht op 2013-04-10.

65 http://www.museumwarsenhoeck.nl/media/files/1988-Van-buitenplaats-tot-steenbakkerij-De-Liesbosch.pdf, bezocht op 2013-04-10. Voor een verklaring van het op het eerste gezicht vreemde dubbele gebruik van het lidwoord, kan verwezen worden naar Van de Velde (2009: 332). 66 http://forum.belgiumdigital.com/fg/sony-alpha-90o-24-6-mp-ff-229058.html, bezocht op 2013-04-10. 
Samengevat: ACI/NCI's met lange infinitieven leken hun beste tijd te hebben gehad aan het einde van het Middelnederlands, maar ondanks de afnemende populariteit van dergelijke constructies, zien we toch dat de NCI in de 18de (en 19de) eeuw populairder wordt en dat de ACI het goed doet in een bepaald hoekje van de grammatica, namelijk de bijzondere relatiefzinnen waarvan eerder sprake was. Voor de ACI/NCI zien we dat de feniks-tendens het gevolg is van analogische aantrekking door een derde constructie, net zoals ook al vastgesteld is bij de fenomenen die behandeld zijn in $\$ 3.1$ en $\$ 3.2$.

\subsection{Korte infinitief bij hulpwerkwoord hoeven}

Een vierde geval van een morfosyntactisch patroon dat tegen de algemene gang van zaken diachroon komt opzetten, is de mogelijkheid om het hulpwerkwoord hoeven te combineren met een 'korte infinitief (ook wel 'naakte infinitief of 'infinitief zonder $t e$ ' genoemd) in de samengestelde tijden, zoals in (61), in plaats van met een 'lange infinitief, zoals in (62).

(61) Tjelpa heeft daarom nog nooit geld hoeven lenen. (NRC 2005, Twente News Corpus)

(62) Dat zou slechts enkele tientallen miljoenen euro's hoeven te kosten, die Duitsland wil betalen (NRC 2005, Twente News Corpus)

Het verschijnsel doet zich niet alleen voor in de samengestelde tijden, maar ook in structuren die homomorf zijn met samengestelde tijden, namelijk wanneer een meervoudige persoonsvorm in de werkwoordelijke eindgroep staat in een bijzin, zoals in (63) (zie ook Haeseryn e.a. 1997: 970 ), en het is nagenoeg verplicht in gevallen waarin hoeven zelf met te gecombineerd wordt, zoals in (64). Daar werkt een soort horror aequiprincipe, dat we ook kennen uit het Engels (he started to run vs. ?? to start to run vs. to start running).

(63) Het mooiste zou zijn als mensen op het aanvraagformulier alleen nog maar een handtekening hoeven zetten (NRC 2005, Twente News Corpus)

(64) Zonder iets te hoeven doen heeft de nee-beweging het eerste punt al binnen. (NRC 2005, Twente News Corpus)

De oppositie tussen de verplichte lange infinitief in de enkelvoudige tijden (die niet homomorf zijn met de samengestelde tijden) enerzijds en de optionele lange infinitief in de samengestelde tijden (en homomorfe patronen) 
doet zich niet alleen voor bij hoeven, maar bij tal van andere hulpwerkwoorden (inchoatief beginnen, duratief zitten etc.). De precieze condities zijn ingewikkeld, en alleen goed te begrijpen in het licht van de diachronie.

De diachronie van de hulpwerkwoorden in het Nederlands wordt beschreven in Van der Horst (2008, hfst. I-VI, §9.5.1-§9.5.2). In grote lijnen samengevat, en dus voorbijgaand aan enige uitzonderingen, komt de diachronie van de selectie van de korte vs. de lange infinitief erop neer dat de oudste hulpwerkwoorden die een infinitief konden regeren (de modalen zullen, mogen, moeten, kunnen, willen, waar zich de niet-modalen gaan en horen (als verbum sentiendi) bij aansluiten ${ }^{67}$ in alle contexten en in alle taalfasen de korte infinitief nemen, terwijl de jongere hulpwerkwoorden ofwel in oudere fasen (Middelnederlands, Vroegnieuwnederlands) alterneren tussen korte en lange infinitief (bv. beginnen, heten, leren), ofwel altijd al met de lange infinitief gecombineerd werden, althans in de niet-samengestelde tijden, (behoren, beloven, blijken, dienen, dreigen, hopen, pogen, proberen etc.). Tegelijkertijd doet zich in de jongere hulpwerkwoorden een 'drift' voor naar steeds meer lange infinitieven. De mate waarin hulpwerkwoorden nog de mogelijkheid hebben een korte infinitief te regeren vertoont lexicale diffusie: sommige houden het langer uit dan andere. Doen en blijven regeren nog consistent de korte infinitief, helpen en leren kunnen zowel met korte als lange infinitief gecombineerd worden, en beginnen en zitten kunnen alleen nog met een lange infinitief (in de enkelvoudige tijden dus). Als we nu even de oeroude hulpwerkwoorden, die immuun lijken te zijn voor de lange-infinitief-drift, buiten beschouwing laten, dan heeft de korte infinitief zijn beste tijd gehad. Hij houdt nog stand in de samengestelde tijden, meestal in de context van infinitivus pro participio (IPP), maar ook daar moet hij terrein prijsgeven. ${ }^{68}$ Bij durven bijvoorbeeld kent de lange infinitief in samengestelde tijden duidelijk uitbreiding (Van der Horst 2008: 1774).

Tegen die achtergrond verwachten we niet hulpwerkwoorden te vinden waarin de korte infinitief in opmars is. Als dat toch het geval is, dan hebben

67 Ik reken zullen hier bij de modalen, wat historisch gezien goed verdedigbaar is. De externe en interne afbakening van de categorie der hulpwerkwoorden is een notoir moeilijke kwestie. Ik volg hier de tamelijk liberale houding van Van der Horst (2008), die daarvoor ondersteuning zoekt in de grammaticalisatieliteratuur, waar gradueel lidmaatschap van morfosyntactische categorieën heel gewoon is.

$68 \mathrm{Er}$ is wel regionale variatie: in het zuidelijke Nederlands is de korte infinitief in de samengestelde tijden van beginnen, een werkwoord dat van oudsher zowel korte als lange infinitieven regeerde maar in niet-samengestelde tijden thans alleen de lange infinitief toelaat in het Noorden, helemaal niet ongebruikelijk. 
we te maken met een soort feniks, zij het van het bescheiden type, want de korte infinitief is natuurlijk niet echt dood. Zulke hulpwerkwoorden zijn, naar het zich laat aanzien, heel schaars, maar voor het werkwoord hoeven lijkt het inderdaad zo te zijn dat de korte infinitief zo veerkrachtig is, dat hij in frequentie toeneemt in samengestelde tijden.

Om dat te onderzoeken ben ik in het Corpus Historische kranten in Nederland op zoek gegaan naar attestaties van het werkwoord (be)hoeven gevolgd door een werkwoord, waarin (be)hoeven ofwel infinitief is, ofwel homomorf is met de infinitief. Het tweede werkwoord is in principe een infinitief, maar door de formele zoektaal kon het ook wel een sterk voltooid deelwoord (op - $n$ ) zijn dat zelf afhing van een lange of korte infinitief, en die gevallen heb ik ook behouden. Horror aequi-gevallen zoals in (64) zijn buiten beschouwing gelaten. In totaal heb ik 3177 treffers overgehouden, verdeeld over drie periodes van 60 jaar. Het aantal lange infinitieven is verre in de meerderheid, maar door de tijd heen doet zich een stijging voor van korte infinitieven. Om wat meer vertrouwen te krijgen in de betrouwbaarheid van de gevonden tendens heb ik vervolgens dezelfde zoekopdracht laten lopen op een stuk van het Twente News Corpus (NRC 2005). Dat leverde in totaal nog eens 220 treffers op. In de mate dat de beide corpora vergelijkbaar zijn, laten de resultaten zien dat het aantal korte infinitieven sinds het midden van de twintigste eeuw spectaculair is toegenomen tot ongeveer $31 \%$. Er is een statistische significante correlatie tussen de tijd en het type infinitieven (Kendall tau $=0,19, \mathrm{p}<0,0001$ ). De tendens is gevisualiseerd in de onderstaande 'Gap plot'.

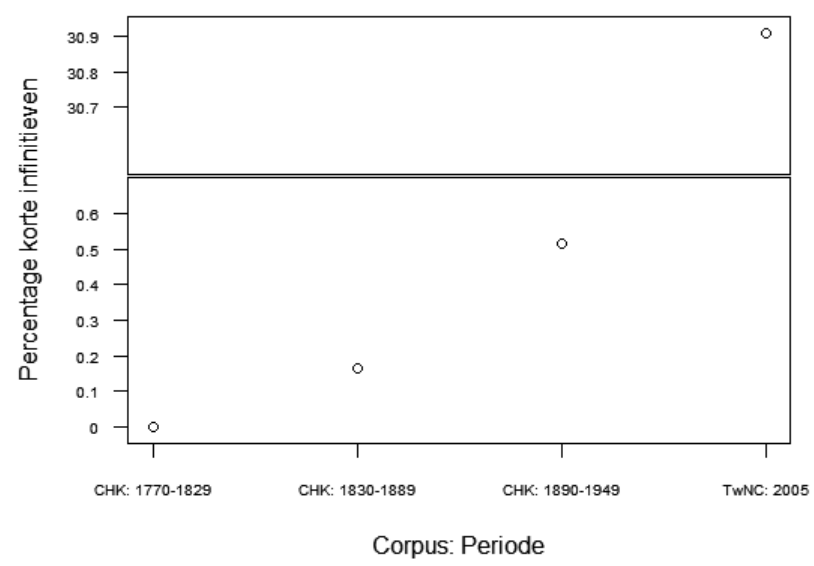

Figuur 3 Percentage korte infinitieven in de werkwoordelijke eindgroep na hoeven in steekproeven in het Corpus historische kranten van Nederland $(\mathrm{CHK})$ en het Twente News Corpus (TwNC) 
De oorzaak van die relatieve toename van korte infinitieven lijkt opnieuw analogie te zijn: hoeven is een deontisch-modaal hulpwerkwoord (met enigszins aparte eigenschappen, zie o.a. Van der Wouden 2001), en wordt gemakkelijker besmet door de kernmodalen kunnen, mogen, moeten, willen, die allemaal de korte infinitief hebben, dan aspectuele hulpwerkwoorden zoals beginnen of zitten, die daar naar betekenis verder van afstaan. Het disruptieve effect is minimaal, want hoeven kende toch al de dubbele mogelijkheid, en er zijn vooralsnog geen aanwijzingen dat hoeven in nietsamengestelde tijden die niet homomorf zijn met de infinitief, een korte infinitief gaat regeren (type *zonder dat hij hoeft werken). We weten uit ander onderzoek in de historische morfosyntaxis dat veel veranderingen 'ongemerkt' binnensluipen (zie De Smet 2012, Van de Velde \& Van der Horst 2013, Van de Velde \& Weerman 2014).

\section{Discussie}

De vier gevalstudies die behandeld zijn in $§ 3$, zijn in principe schoolvoorbeelden van aan de gang zijnde grammaticalisatie: de TVR wordt als grammaticalisatie behandeld in Van de Velde (2009, 2011), de wat betreft-constructie is een typisch geval van grammaticalisatie tot een voorzetseluitdrukking (zie Vranjes 2012), de NCI wordt als grammaticalisatie behandeld in Noël \& Colleman (2009) en de ontwikkeling van de hulpwerkwoorden is ook uitvoerig bestudeerd binnen de grammaticalisatieliteratuur. In al die gevallen krijgen we de beste kijk op de feiten als we een constructionele visie op grammaticalisatie hanteren (zie o.a. Trousdale 2010, 2012; Gisborne \& Patten 2011; Fried 2013; Traugott \& Trousdale 2013 voor de theoretische achtergrond en motivering van die benadering). Het resultaat van het grammaticalisatieproces is in zo'n visie niet per se een morfeem of een grammaticaal woord, maar een constructie met variabel in te vullen open plekken. ${ }^{69}$ Voor de TVR en de NCI ligt dat voor de hand. De feitelijke

69 Er bestaat discussie over de vraag of het wel verstandig is zulke 'constructionalisaties' onder de rubriek van grammaticalisatie te laten vallen (zie o.a. Noël 2007). Zolang het resultaat van de constructionalisatie valt onder wat verstaan wordt onder grammaticalisatieproducten (functiewoorden, morfemen etc.) lijkt me dat geen probleem. De vraag is dan natuurlijk wat wel en wat niet valt onder grammaticalisatieproducten. Ik hang hier een relatief brede visie op grammaticalisatie aan, als een proces van een toegenomen grammaticale, procedurele betekenis aan de kant van de signifié die meestal gepaard gaat met een afname van de autonomie aan de zijde van de signifiant (wat betekent dat die signifiant vooral voorkomt in combinatie met andere elementen en dan pas zijn functie krijgt, b.v. lidwoorden, hulpwerkwoorden, $\mathrm{V}_{1} / \mathrm{V}_{2} / \mathrm{V}$-laat etc.), en een expansie in de gebruikscontexten (zie Himmelmann 2004). 
attestaties van deze constructies variëren lexicaal, binnen strengere of minder strenge semantische en syntactische restricties. Voor de wat betreft-constructie en de toenadering van hoeven tot de kernmodalen kan de taalkundige analist in principe uit de voeten met een klassieke opvatting van grammaticalisatie die zich concentreert op een lexicaal-specifieke streng als einddoel van het grammaticalisatieproces, maar ook hier blijkt een constructionele aanpak inzichtelijker: voor het ontstaan van complexe preposities is dat voor het Engels aangetoond door Hoffmann (2004) en voor het Nederlands door Vranjes (2012). Bij hoeven zou een klassieke grammaticalisatie-aanpak wellicht eerder voorspellen dat er een toename is van de lange infinitief. Dat is immers wat je bij de jongere hulpwerkwoorden ziet (Van der Horst 2008).

De constructionele visie benadrukt dat de semantische en syntactische veranderingen van de elementen in kwestie slechts plaatsvinden door analogie met andere instanties van constructies. Het abstracte sjabloon van de overkoepelende constructie sanctioneert de specifieke grammaticalisatiegevallen. Hoffmann kan op die manier onder andere verklaren waarom ongebruikelijke voorzetseluitdrukkingen zoals by dint of ondanks hun beperkte gebruiksfrequentie toch grammaticaliseren, terwijl frequentietoename traditioneel gezien wordt als een symptoom of zelfs als de drijfveer achter grammaticalisatie. De taalgebruiker heeft immers een idee van het semantische en formele silhouet van een complexe prepositie (in dit geval [ ${ }_{\mathrm{PP}} \mathrm{P} \mathrm{N}$ of $\left.\mathrm{N}\right]$ ), en kan dat silhouet gebruiken om compositioneel opgebouwde syntactische strengen 'instant' te laten grammaticaliseren. In dat opzicht hoeft grammaticalisatie niet altijd te leiden tot paradigmaversmalling (Lehmann 1985), maar kan het ook leiden tot paradigmatische proliferatie: een steeds groter en gevarieerder groep elementen verwerft lidmaatschap van die categorie (zie ook Van Bogaert 2010; Van de Velde 2011; Verveckken 2012). De nadruk op analogie als veranderingesmechanisme sluit goed aan bij wat de gevalstudies in §3 laten zien: morfosyntactische aanpassingen (bijv. de combinatie met korte infinitief) als deelprocessen van grammaticalisatieontwikkelingen (bijv. de voortschrijdende grammaticalisatie van hoeven tot modaal) kunnen bijgestuurd worden door de semantische en vormelijke druk van naburige instanties van constructies (bijv. de oude kernmodalen).

Het interessante van zo'n constructionele visie op grammaticalisatie, waarbij het grammaticalisatieproduct nog intern transparant opgebouwd kan zijn, is verder dat er zich binnenin de constructie nog andere grammaticalisatieprocessen kunnen voltrekken - het taalkundige equivalent van het 'un train peut en cacher un autre' aan Franse overwegen. Een 
voorbeeld: de TVR is een tot kopbepaling gegrammaticaliseerde constructie die teruggaat op een vrije relatiefzin met een werkwoord dat een evidentiële of epistemisch-modale betekenis kan hebben. Het Nederlands heeft verder een NCI die zich tot evidentiële constructie ontwikkeld heeft. Het is dan ook mogelijk die evidentiële NCI-constructie in te schuiven in de TVR om zodoende een evidentiële kopbepaling te fabriceren in de nominale constituent. Dat is ook werkelijk gebeurd in het Nederlands, zie (54), (55), (57).

Doordat op die manier een getrapte structuur van grammaticalisatiegevallen verkregen wordt, kunnen conflicten optreden: de TVR kan een populaire constructie worden door de grammaticalisatie van de kopbepalingkavel, maar als die wel vaart bij het bestaan van objects-extrapositie, dan komt de grammaticalisatie van de TVR in conflict met een toenemende grammaticalisatie van de tweede zinspool, die objects-extrapositie juist inperkt. Het is in dat soort conflicten dat syntactische feniksen kunnen ontstaan.

In Tabel 3 wordt een overzicht gegeven van de gevallen die in dit artikel behandeld zijn, en wat de bevorderende factor geweest is om de 'feniksen' uit hun as te laten herrijzen. In alle vier de gevallen gaat het om analogie met andere constructies.

Tabel 3 Overzicht van de gevalstudies

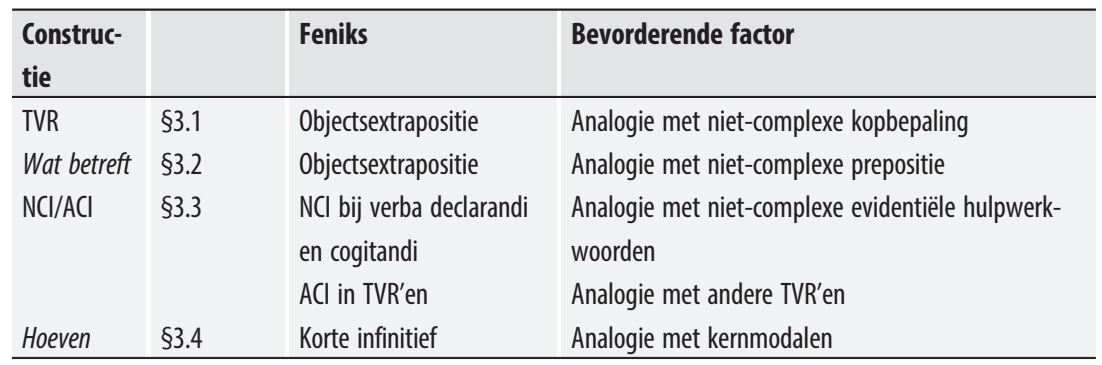

\section{$5 \quad$ Conclusie}

Aan het onderzoek dat behandeld is in dit artikel, zijn twee grote conclusies te koppelen. Allereerst de grote rol van analogie, soms op heel lokaal niveau, in historische processen. Daarmee wordt aansluiting gezocht bij heel wat ander corpusgedreven onderzoek waar de rol van analogie ten volle erkend wordt (zie eerder aangehaalde referenties, §1). Ten tweede: 
het idee dat taalveranderingen soms vreemde koerswijzigingen kunnen ondergaan door de impact van het omgevende grammaticale systeem. Taalgebruikers die een nieuwe constructie in het leven roepen, kunnen op hun pad hinder ondervinden van de grammaticale omgeving. In principe kunnen dan twee dingen gebeuren. Een eerste mogelijkheid is natuurlijk dat de opmars van die nieuwe constructie afgeremd of stopgezet wordt. Dat komt vaak voor: in het (laat-)Nieuwnederlands is bijvoorbeeld de ACI niet goed van de grond gekomen omdat die hinder ondervindt van de SOVstructuur van het Nederlands zodat de 'accusativus' niet (noodzakelijk) tussen het vervoegde werkwoord en zijn infinitief komt, in tegenstelling tot wat het geval is in het Engels (zie Fischer 1994) en ook de TVR wordt in zijn ontwikkeling enigszins geremd in het Nederlands door de niet-rechtsperifere inhoudskernen (zie De Smet \& Van de Velde 2013). Een tweede mogelijkheid is echter dat de taalgebruiker doorzet met de nieuwe constructie en een aanpassing doet aan de structuur van zijn grammatica, zij het vaak heel erg lokaal (zie Joseph 1992 over 'local generalizations').$^{70}$ De taalgebruiker kan bijvoorbeeld enthousiast gebruik maken van nieuwe evidentiële constructies, en tegen de gang van de grammatica in, werkwoorden die daar semantisch voor in aanmerking komen, in een 'verouderde' NCI gebruiken, of hij kan toch doorgaan met het gebruik van wat betreft als complexe prepositie, en tegen de gang van de grammatica in gebruik maken van objectsextrapositie, of hij kan de groep deontisch-modale hulpwerkwoorden uitbreiden met hoeven en het morfosyntactisch gedrag daarvan lichtjes bijsturen onder invloed van de kernmodalen. Daardoor lijkt het alsof oude syntactische constructies opflakkeren. Zoals in $§ 2$ benadrukt is, moet hier niet gedacht worden aan een bewust en doordacht ontwerp door de taalgebruiker, maar aan een onbewust analogisch proces, dat bij herhaling post kan vatten in de taal. Eens te meer blijkt dat een goed begrip van het taalsysteem niet om de historische dimensie heen kan.

70 Zo'n aanpassing aan de structuur in plaats van aan de nieuwe constructie doet een beetje denken aan de situatie in het gedicht Die Lösung van Berthold Brecht, waarin de absurde 'oplossing' gesuggereerd wordt om bij een conflict tussen het volk en de regering niet de regering af te zetten, maar het volk: Nach dem Aufstand des 17. Juni / Ließ der Sekretär des Schriftstellerverbands / In der Stalinallee Flugblätter verteilen / Auf denen zu lesen war, daß das Volk / Das Vertrauen der Regierung verscherzt habe / Und es nur durch verdoppelte Arbeit / Zurückerobern könne. Wäre es da / Nicht doch einfacher, die Regierung / Löste das Volk auf und / Wählte ein anderes? 


\section{Bibliografie}

Abney, Steven P. (1987). The English noun phrase in its sentential aspects. Proefschrift, MIT.

Auwera, Johan van der (2012). 'Wat het Nederlands ons kan leren over de Jespersencyclus'. Nederlandse Taalkunde $17,403-413$ \& 423-425.

Auwera, Johan van der \& Dirk Noël (2011). 'Raising: Dutch between English and German'. Journal of Germanic Linguistics 23, 1-36.

Barbiers, Sjef (1995). The syntax of interpretation. Den Haag: Holland Academic Graphics.

Behaghel, Otto (1932). Deutsche Syntax. Eine geschichtliche Darstellung. Band IV. Worstellung. Periodenbau. Heidelberg: Winter.

Bogaert, Julie Van (2010). 'A constructional taxonomy of I think and related expressions: accounting for the variability of complement-taking mental predicates'. English Language and Linguistics 14(3), 399-427.

Boogaart, Ronny (2012). 'Wat betreft betreft'. Vaktaal 24(4), 12-13.

Boogaart, Ronny, Timothy Colleman \& Gijsbert Rutten (red.) (2014). The extending scope of construction grammar. Berlijn: De Gruyter.

Boye, Kasper \& Peter Harder (2012). A usage-based theory of grammatical status and grammaticalization. Language 88(1), 1-44.

Bree, Cor van (1996). Historische taalkunde. $2^{\mathrm{e}}$ druk. Leuven: Acco.

Broekhuis, Hans \& Evelien Keizer (2012). Syntax of Dutch. Nouns and noun phrases. Volume 1. Amsterdam: Amsterdam University Press.

Butler, Chris (1985). Statistics in linguistics. Oxford: Blackwell.

Bybee, Joan (2003). 'Mechanisms of change in grammaticalization: the role of frequency'. In: Brian D. Joseph \& Richard D. Janda (red.), The handbook of historical linguistics, 602-623. Oxford: Blackwell.

Bybee, Joan (2007). 'Diachronic linguistics'. In: Dirk Geeraerts \& Hubert Cuyckens (red.), The handbook of cognitive linguistics, 945-987. Oxford: Oxford University Press.

Bybee, Joan (2010). Language, usage, and cognition. Cambridge: Cambridge University Press.

Bybee, Joan, Revere D. Perkins \& William Pagliuca (1994). The evolution of grammar: tense, aspect, and modality in the languages of the world. Chicago: University of Chicago Press.

Colleman, Timothy \& Dirk Noël (2009). 'Gezegd worden + te-infinitief: een verouderde evidentiële constructie'. Tijdschrift voor Nederlandse Taal- en Letterkunde 125, 385-403.

Colleman, Timothy \& Dirk Noël (2012). "The Dutch evidential NCI: A case of constructional attrition'. Journal of Historical Pragmatics 13(1), 1-28.

Company Company, Concepción (2006a). 'Zero in syntax, ten in pragmatics: subjectification as syntactic cancellation'. In: Angeliki Athanasiodou, Costas Canakis \& Bert Cornillie (red.), Subjectification: Various paths to subjectivity, 375-398. Berlijn: De Gruyter.

Company Company, Concepción (2006b). 'Subjectification of verbs into discourse markers: semantic-pragmatic change only?' Belgian Journal of Linguistics 20, 97-121.

Coppen, Peter-Arno (2001). 'Linguïstisch Miniatuurtje LXXIX: Linguïstische Romantici'. <http:// www.neder-l.nl/bulletin/2001/04/010434.html>, bezocht op 2014-07-18.

Coppen, Peter-Arno (2006). 'Linguïstisch Miniatuurtje CXV: Hier wordt iets laten zien'. <http:// www.neder-l.nl/newindex.html?http://www.neder-l.nl/bulletin/2006/10/o61026.html>, bezocht op 2014-07-18.

Coussé, Evie (2009). 'Focus, complexiteit en extrapositie. Over de veranderende woordvolgorde in het Nederlands'. Neerlandistiek.nl 9(4), 1-32.

Croft, William (2000). Explaining language change. An evolutionary approach. Harlow: Longman. 
Dąbrowska, Ewa (2012). 'Different speakers, different grammars. Individual differences in native language attainment'. Linguistic Approaches to Bilingualism 2, 219-253.

Dahl, Östen (1979). 'Typology of sentence negation'. Linguistics 17, 79-106.

Davidse, Kristin, An Van linden \& Jean-Christophe Verstraete (2010). 'Introduction'. In: An Van linden, Jean-Christophe Verstraete \& Kristin Davidse (in samenwerking met Hubert Cuyckens) (red.), Formal evidence in grammaticalization research, 1-16. Amsterdam: John Benjamins.

Dikken, Marcel den (2005). 'Transparent, free ... and polarised: The (poli)tics of polarity in transparent free relatives'. In: Hans Broekhuis, Norbert Corver, Riny Huybregts, Ursula Kleinhenz \& Jan Koster (red.), Organizing grammar, 97-107. Berlijn: De Gruyter.

Duinhoven, Anton M (1991). 'Dat siet men wit ende reine wesen. A.c.i.-constructies in het Nederlands'. De Nieuwe Taalgids 84, 409-430.

Fischer, Olga (1994). 'The fortunes of the Latin-type accusative and infinitive construction in Dutch and English compared'. In: Toril Swan, Endre Morck, Olaf Jansen Westvik (red.), Language change and language structure in a comparative perspective, 91-133. Berlijn: Mouton de Gruyter.

Fischer, Olga (2007). Morphosyntactic change. Functional and formal perspectives. Oxford: Oxford University Press.

Fischer, Olga (2008). 'On analogy as the motivation for grammaticalization'. Studies in Language $32(2), 336-382$.

Fischer, Olga (2011). 'Grammaticalization as analogically driven change'. In: Heiko Narrog \& Bernd Heine (red.), The Oxford handbook of grammaticalization, 31-42. Oxford: Oxford University Press.

Foolen, Ad (1993). De betekenis van partikels: een dokumentatie van de stand van het onderzoek met bijzondere aandacht voor maar. Proefschrift, K.U. Nijmegen.

Fried, Mirjam (2013). 'Principles of constructional change'. In: Thomas Hoffmann \& Graeme Trousdale (red.), The Oxford handbook of Construction Grammar, 419-437. Oxford: Oxford University Press.

Gelderen, Elly van (2011). The linguistic cycle: language change and the language faculty. Oxford: Oxford University Press.

Giacalone Ramat, Anna (1998). 'Testing the boundaries of grammaticalization'. In: Anna Giacalone Ramat \& Paul J. Hopper (red.), The limits of grammaticalization, 227-270. Amsterdam: John Benjamins.

Gisborne, Nikolas \& Amanda Patten (2011). 'Construction grammar and grammaticalization'. In: Heiko Narrog \& Bernd Heine (red.), The Oxford handbook of grammaticalization, 92-104. Oxford: Oxford University Press.

Groot, Albert W. de (1949). Structurele syntaxis. Den Haag: Servire.

Grosu, Alexander (2003). 'Transparent' free relatives as a special instance of 'standard' free relatives'. In: Martin Coene \& Yves D'hulst (red.), From DP to NP. Vol I. The syntax and semantics of noun phrases, 139-178. Amsterdam: John Benjamins.

Haeseryn, Walter e.a. (1997). Algemene Nederlandse spraakkunst. $2^{\mathrm{e}}$ druk. Groningen: Nijhoff.

Haspelmath, Martin (2000). 'Why can't we talk to each other?'. Lingua 110, 235-255.

Heath, Jeffrey (1998). 'Hermit crabs: formal renewal of morphology by phonologically mediated affix substitution'. Language 74, 728-759.

Heine, Bernd (2003). 'Grammaticalization'. In: Brian D. Joseph \& Richard D. Janda (red.), The handbook of historical linguistics, 575-601. Oxford: Blackwell.

Heine, Bernd \& Tania Kuteva (2002). World lexicon of grammaticalization. Cambridge: Cambridge University Press.

Himmelmann, Nikolaus P. (2004). 'Lexicalization and grammaticization: opposite or orthogo- 
nal?'. In: Walter Bisang, Nikolaus Himmelmann, Björn Wiemer (red.), What makes grammaticalization? A look from its fringes and its components, 21-42. Berlijn: Mouton de Gruyter.

Hoeksema, Jack (1998). 'Een ondode kategorie: de genitief. Tabu 28, 162-167.

Hoffmann, Sebastian (2004). 'Are low-frequency complex prepositions grammaticalized? On the limits of corpus data - and the importance of intuition'. In: Hans Lindquist \& Christian Mair (red.), Corpus approaches to grammaticalization in English, 171-210. Amsterdam: John Benjamins.

Hoffmann, Thomas \& Graeme Trousdale (red.) (2013). Handbook of Construction Grammar. Oxford: Oxford University Press.

Hopper, Paul J. (1975). The syntax of the simple sentence in Proto-Germanic. Den Haag: Mouton.

Horst, Johannes van der (1995). Analytische taalkunde. Groningen: Nijhoff.

Horst, Johannes van der (2008). Geschiedenis van de Nederlandse syntaxis. Leuven: Universitaire Pers Leuven.

Huddleston, Rodney D. \& Geoffrey K. Pullum (red.) (2002). The Cambridge grammar of the English language. Cambridge: Cambridge University Press.

Hüning, Matthias.(1999). Woordensmederij. De geschiedenis van het suffix -erij. Utrecht: LOT Dissertation Series.

Joseph, Brian D (1992). 'Diachronic explanation: Putting the speaker back into the picture'. In: Garry W. Davis \& Gregory K. Iverson (red.), Explanations in historical linguistics, 123-144. Amsterdam: John Benjamins.

Keller, Rudi (1990). Sprachwandel; von der unsichtbaren Hand in der Sprache. Tübingen: Francke.

Kluck, Marlies (2011). Sentence amalgamation. Utrecht: LOT Dissertation Series.

Lakoff, George (1988) [1974]. 'Syntactic amalgams'. In: Eric Schiller, Barbara Need, Douglas Varley \& William H. Eilfort (red.), The best of CLS: a selection of out-of-print papers from 1968 to 1975, 25-45. Chicago: The Chicago Linguistic Society.

Leech, Geoffrey, Marianne Hundt, Christian Mair \& Nicholas Smith (2009). Change in contemporary English. A grammatical study. Cambridge: Cambridge University Press.

Lehmann, Christian (1985). 'Grammaticalization: synchronic variation and diachronic change'. Lingua e Stile 20, 303-318.

Lemon, J. (2006). 'Plotrix: a package in the red light district of R'. R-News 6(4), 8-12.

Lubbe, Hendricus van der (1958). Woordvolgorde in het Nederlands: een synchrone structurele beschouwing. Assen: Van Gorcum.

Lyons, Christopher (1999). Definiteness. Cambridge: Cambridge University Press.

Mair, Christian (2004). 'Corpus linguistics and grammaticalisation theory'. In: Hans Lindquist \& Christian Mair (red.), Corpus approaches to grammaticalization in English, 121-150. Amsterdam: John Benjamins.

Marle, Jaap van \& Geert A.T. Koefoed (1980). 'Over Humboldtiaanse taalveranderingen, morfologie en de creativiteit van taal'. Spektator 10, 111-147.

McCawley, James D (1988). The syntactic phenomena of English. 2 vols. Chicago: Chicago University Press.

Meyer, David, Achim Zeileis \& Kurt Hornik (2006). 'The strucplot framework: Visualizing multiway contingency tables with vcd. Journal of Statistical Software 17(3), 1-48.

Meyer, David, Achim Zeileis \& Kurt Hornik (2013). vcd: Visualizing Categorical Data. R package version 1.3-1.

Mithun, Marianne (1991). "The role of motivation in the emergence of grammatical categories: the grammaticization of subjects'. In: Elizabeth C. Traugott \& Bernd Heine (red.), Approaches to grammaticalization. Volume II. Focus on types of grammatical markers, 159-184. Amsterdam: John Benjamins.

MNW: Middelnederlandsch Woordenboek (1998). 's-Gravenhage: Sdu. Cd-romversie van Eelco 
Verwijs \& Jacob Verdam. 1885-1952. Middelnederlandsch Woordenboek. 's-Gravenhage: Nijhoff.

Noël, Dirk (2007). 'Diachronic construction grammar and grammaticalization theory'. Functions of Language 14(2), 177-202.

Noël, Dirk \& Timothy Colleman (2009). 'The nominative and infinitive in English and Dutch'. Languages in Contrast 9(1), 144-181.

Noël, Dirk \& Timothy Colleman (2010). 'Believe-type raising-to-object and raising-to-subject in English and Dutch. A contrastive investigation in diachronic construction grammar'. International Journal of Corpus Linguistics 15(2), 157-182.

OED: James Murray, Henry Bradley \& William Craigie (1993). The Oxford English Dictionary. Oxford: Oxford University Press. http://www.oed.com.

Paul, Hermann (1898). Prinzipien der Sprachgeschichte. Derde uitgave. Halle: Max Niemeyer.

Payne, John \& Rodney D. Huddleston (2002). 'Nouns and noun phrases'. In: Rodney D. Huddleston \& Geoff K. Pullum (red.), The Cambridge grammar of the English language, 423-523. Cambridge: Cambridge University Press.

Plank, Frans (1984). 'The modals story retold'. Studies in Language 8, 305-364.

Plank, Frans (2004). 'Inevitable reanalysis. From local adpositions to approximative adnumerals, in German and wherever'. Studies in Language 28, 165-201.

Ramat, Paolo \& Davide Ricca (1998). 'Sentence adverbs in the languages of Europe'. In: Johan van der Auwera (red.), Adverbial constructions in the languages of Europe, 187-275. Berlijn: De Gruyter.

Riemsdijk, Henk van (2000a). 'Binnenstebuitenbouw: enkele observaties over transparante vrije relatiefzinnen'. In: Steven Gillis, Jan Nuyts \& Johan Taeldeman (red.), Met taal om de tuin geleid, 437-448. Antwerpen: UIA.

Riemsdijk, Henk van (200ob). 'Free relatives inside out: transparent free relatives as grafts'. In: Bozena Rozwadowska (red.), Proceedings of the 1999 PASE Conference, 223-233. Breslau: Universiteit van Breslau.

Roey, Jacques van (1974). A contrastive description of English and Dutch noun phrases. Brussel: AIMAV.

Roose, H. (1956). 'Kategorieën van voorgeplaatste bepalingen bij substantieven'. Levende Talen 474-483.

Rosenbach, Annette (2010). 'How synchronic gradience makes sense in the light of language change (and vice versa)'. In: Elizabeth C. Traugott \& Graeme Trousdale (red.), Gradience, gradualness and grammaticalization, 149-179. Amsterdam: John Benjamins.

Schelfhout, Carla, Peter-Arno Coppen \& Nelleke Oostdijk (2004). 'Transparent free relatives'. In: Sylvia Blaho, Luis Vicente \& Mark De Vos (red.), Proceedings of CONSOLE XII. (http://www.sole.leidenuniv.nl/content_docs/ConsoleXII2003pdfs/schelfhout-2003.pdf).

Schutter, Georges De (1998). 'The noun phrase in Dutch'. Leuvense Bijdragen 86, 309-356.

Schutter, Georges De (1999). 'Het achterveld in de nominale constituent in het Nederlands'. Leuvense Bijdragen 88, 323-354.

Smet, Hendrik De (2009). 'Analyzing reanalysis'. Lingua 119, 1728-1755.

Smet, Hendrik De (2010). 'Grammatical interference: subject marker for and phrasal verb particle out'. In: Elizabeth C. Traugott \& Graeme Trousdale (red.), Gradualness, gradience and grammaticalization, 75-104. Amsterdam: John Benjamins.

Smet, Hendrik De (2012). 'The course of actualization'. Language 88, 601-633.

Smet, Hendrik De \& Jean-Christophe Verstraete (2006). 'Coming to terms with subjectivity'. Cognitive Linguistics 17, 365-392.

Smet, Hendrik De \& Freek Van de Velde (2013). 'Serving two masters: form-function friction in syntactic amalgams'. Studies in Language 37, 534-565. 
Smith, John-Charles (2006). 'How to do things without junk: the refunctionalization of a pronominal subsystem between Latin and Romance'. In: Jean-Pierre Y. Montreuil (red.), New perspectives on Romance linguistics. Volume II: Phonetics, phonology and dialectology, 183205. Amsterdam: John Benjamins.

Timberlake, Alan (2007). Aspect, tense, mood. In: Timothy Shopen (red.), Language typology and syntactic description. Vol. III: Grammatical categories and the lexicon. $2^{\mathrm{e}}$ uitgave, 280-333. Cambridge: Cambridge University Press.

Traugott, Elizabeth C. (2003). 'Constructions in grammaticalization'. In: Brian D. Joseph \& Richard D. Janda (red.), The handbook of historical linguistics, 624-647. Oxford: Blackwell.

Traugott, Elizabeth C. \& Greame Trousdale (2013). Constructionalization and constructional changes. Oxford: Oxford University Press.

Trousdale, Graeme (2010). 'Issues in constructional approaches to grammaticalization'. In: Ekaterini Stathi, Elke Gehweiler \& Ekkehard König (red.), Grammaticalization: current views and issues, 51-71. Amsterdam: John Benjamins.

Trousdale, Graeme (2012). 'Grammaticalization, constructions and the grammaticalization of constructions'. In: Kristin Davidse, Tine Breban, Lieselotte Brems \& Tanja Mortelmans (red.), Grammaticalization and language change: new reflections, 167-198. Amsterdam: John Benjamins.

Twente News Corpus, zie: http://wwwhome.cs.utwente.nl/^druid/TwNC/TwNC-main.html.

Velde, Freek Van de (2004). 'De Middelnederlandse onpersoonlijke constructie en haar grammaticale concurrenten. Semantische motivering van de argumentstructuur'. Nederlandse Taalkunde 9, 48-76.

Velde, Freek Van de (2007). 'Interpersonal modification in the English noun phrase'. Functions of Language 14, 203-230.

Velde, Freek Van de (2009). De nominale constituent. Structuur en geschiedenis. Leuven: Universitaire Pers Leuven.

Velde, Freek Van de (2010). 'Ontwikkelingen in de linkerperiferie van de nominale constituent'. Nederlandse Taalkunde 15, 220-237.

Velde, Freek Van de (2011). 'Left-peripheral expansion of the English NP'. English Language and Linguistics 15, 387-415.

Velde, Freek Van de (2012). 'PP extraction and extraposition in Functional Discourse Grammar'. Language Sciences 34, 433-454.

Velde, Freek Van de \& Johannes van der Horst (2013). 'Homoplasy in diachronic grammar'. Language Sciences 36, 66-77.

Velde, Freek Van de \& Fred Weerman (2014). 'The resilient nature of adjectival inflection in Dutch'. In: Petra Sleeman, Freek Van de Velde, \& Harry Perridon (red.), Adjectives in Germanic and Romance, 113-145. Amsterdam: John Benjamins.

Verstraete, Jean-Christophe (2003). 'Preverbal positions in three Germanic languages. The role of scope as a functional principle'. Languages in contrast 4(1), 105-136.

Verveckken, Katrien (2012). 'Towards a constructional account of high and low frequency binominal quantifiers in Spanish'. Cognitive Linguistics 23(2), 421-478.

Vincent, Nigel (1995). 'Exaptation and grammaticalization'. In: Hennig Andersen (red.), Historical linguistics 1993, 433-445. Amsterdam: John Benjamins.

Vranjes, Jelena (2012). Voorzetseluitdrukkingen in het Nederlands sinds de 16de eeuw: een diachroon corpusonderzoek. Ongepubliceerde masterproef. KU Leuven, Leuven.

Weijnen, Antonius A. (1971). Schets van de geschiedenis van de Nederlandse syntaxis. Assen: Van Gorcum.

Wilder, Chris (1999). 'Transparent free relatives'. In: Kimary N. Shahin, Susan Blake \& Eun-Sook 
Kim (red.), Proceedings of the Seventeenth West Coast Conference on Formal Linguistics, 685699. Cambridge: Cambridge University Press.

Willis, David (2010). 'Degrammaticalization and obsolescent morphology: evidence from Slavonic'. In: Ekaterini Stathi, Elke Gehweiler \& Ekkehard König (red.), Grammaticalization: current views and issues, 151-178 Amsterdam: John Benjamins.

Wouden, Ton van der (2001). 'Three modal verbs'. In: Sheila Watts, Jonathan \& Hans-Joachim Solms (red.), Zur Verbmorphologie germanischer Sprachen, 189-210. Tübingen: Niemeyer.

WNT: Woordenboek der Nederlandsche Taal (2003). 's-Gravenhage: Sdu. Cd-romversie van Matthias de Vries \& Lammert te Winkel. 1882-1998. Woordenboek der Nederlandsche taal. 'sGravenhage: Nijhoff.

Yoo, Eun-Jung (2008). 'Transparent Free Relatives in English'. In: Stefan Müller (red.), Proceedings of the 15th International Conference on Head-Driven Phrase Structure Grammar, National Institute of Information and Communications Technology, Keihanna, 294-304. Stanford: CSLI Publications.

Zajicek, Jacques (1970). 'Réflexions sur l'accusativus cum infinitivo'. Nieuwe Taalgids 63, 198-208. Zeileis, Achim, David Meyer \& Kurt Hornik (2007). 'Residual-based shadings for visualizing (conditional) independence'. Journal of Computational and Graphical Statistics 16(3), 507-525.

Zwart, Jan-Wouter (2006). 'Over het enten van interpolaties'. Tabu 35, 163-180.

Zwart, Jan-Wouter (2011). The syntax of Dutch. Cambridge: Cambridge University Press.

\section{Over de auteur}

Freek Van de Velde, KU Leuven / FWO-Vlaanderen, Taalkunde - Onderzoekseenheid QLVL, Blijde Inkomststraat 21, bus 3308, BE-30oo Leuven E-mail: freek.vandevelde@kuleuven.be 
